\title{
Sorption and desorption of sex hormones in soil- and sediment-water systems: A review
}

\author{
Xiong Dai ${ }^{1}$, Xingjian Yang ${ }^{1,2, *}$, Bihai $\mathrm{Xie}^{3}$, Jiajia Jiao ${ }^{1}$, Xiuping Jiang ${ }^{1}$, Chengyu Chen ${ }^{1}$, Zhen Zhang ${ }^{1}$, \\ Zhili He ${ }^{1}$, Hang Lin ${ }^{1}$, Weisong Chen ${ }^{1}$, Yongtao $\mathrm{Li}^{1}{ }^{\text {, }}$ \\ 1 College of Natural Resources and Environment, Joint Institute for Environment \& Education, South China Agricultural University, \\ Guangzhou 510642, China \\ 2 Key Laboratory of Southern Farmland Pollution Prevention and Control, Ministry of Agriculture and Rural Affairs, Hunan Division of GRG \\ Metrology and Test, Changsha 410000, China \\ 3 Dongguan Institute of Food Crops and Flowers, Dongguan 523063, China
}

\section{H I G H L I G H T S}

- This study reviewed the sorption of sex hormones onto soils and sediment.

- Hydrophobic and other specific interactions are the main sorption mechanisms.

- The sorption of sex hormones is affected by $\mathrm{pH}$, temperature, and ionic strength.

- Future research should focus on the coupled leaching-sorption processes.
GRAPHICAL ABSTRACT

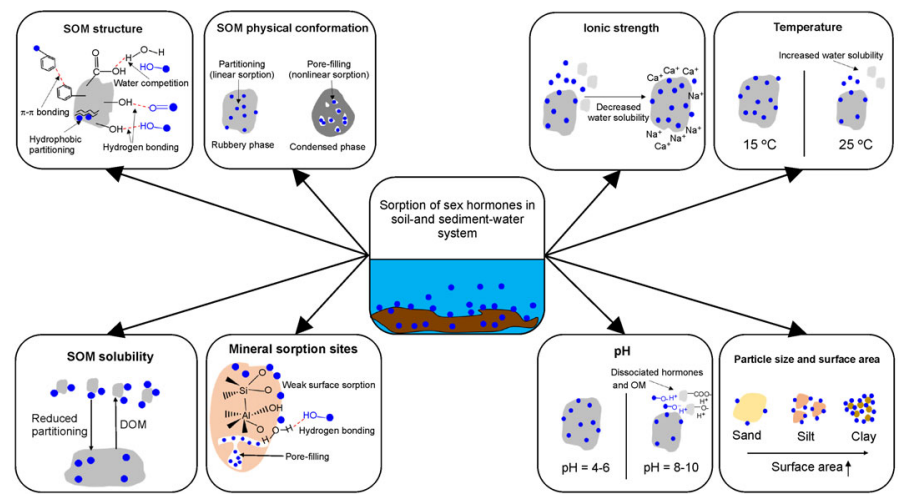

A B S T R A C T

Sex hormones are a group of potent endocrine disruptors that can be released into agricultural soils and sediment via wastewater discharge and manure fertilization. Sorption represents a critical determinant for the transport potential and risks of sex hormones in the environment. Therefore, this study reviewed the sorption and desorption mechanisms of sex hormones in soil- and sedimentwater systems, and summarized the effects of various factors on sorption and desorption processes. A total of 359 set of sorption data were collected from the literature. Sex hormones were mostly described by the linear model. The sorption magnitudes $\left(\log K_{\mathrm{oc}}\right)$ of estrogens, androgens, and progestins were in the range of $2.77-3.90,2.55-4.18$, and $2.61-4.39$, respectively. The average $\log K_{\mathrm{oc}}$ values of the sex hormones were significantly correlated with their $\log K_{\text {ow }}$ values $\left(R^{2}=0.13\right.$, $p<0.05$ ), while the $R^{2}$ values were much lower than those when fewer sex hormones were included for analysis. In addition, the $K_{\mathrm{d}}$ values of most sex hormones were significantly correlated with the OC\% of soils and sediment $\left(R^{2}=0.16-0.99, p<0.05\right)$, but were insignificantly correlated with the particle size distribution and surface area. These results indicated that hydrophobic partitioning interaction and other specific interactions are responsible for sex hormone uptake in soil- and sediment-water systems. The sorption of sex hormones in soil- and sediment-water systems can also be affected by other environmental variables, including $\mathrm{pH}$, temperature, and ionic strength. Future studies should focus on the coupled leaching-sorption processes in manure-water-soil systems under field-scale conditions.

(c) Higher Education Press 2020

\footnotetext{
* Corresponding authors

E-mail address: xjyang@scau.edu.cn (X. Yang); yongtao@scau.edu.cn (Y. Li)
} 


\section{Introduction}

The occurrence of biologically active sex hormones (i.e., natural and synthetic androgens, estrogens, and progestins) in the environment is of concern (Wang et al., 2011; Liu et al., 2012a). At trace levels, these compounds can strongly affect the reproduction behaviors (Zeilinger et al., 2009; Runnalls et al., 2013), gene expression (Zucchi et al., 2012; Zucchi et al., 2013), or endogenous hormone levels of exposed fish (Runnalls et al., 2013). Sex hormones are produced by testes, placenta, ovaries, and adrenal glands of humans and animals (O'Loughlin et al., 2004; Adeel et al., 2017), or are synthesized and used for oral contraception (Zeilinger et al., 2009), hormone replacement therapy (Lobo, 1992), treatment of endometrial carcinoma (Gambrell et al., 1983), and animal growth promotion (Fent, 2015). Despite their widespread use, existing studies only reported the excretion and environmental discharge of a few sex hormones (Besse and Garric, 2009; Runnalls et al., 2010; Zhang et al., 2014; Kavanaugh et al., 2015; Adeel et al., 2017; Odom et al., 2017). For example, the worldwide discharge of natural and synthetic estrogens (2017) by 7 billion human population was estimated to be $30700 \mathrm{~kg}$, which only accounted for $37 \%$ of that by livestock in the United States and the European Union (83 $000 \mathrm{~kg}$ ) (Adeel et al., 2017). The total excretions of endogenous estrogens, androgens, and progestins (2000) by farm animals in the European Union and the United States were estimated to be 356.7 ton and 332.4 ton, respectively (Lange et al., 2002). The total excretion of seven natural steroid hormones (2014) by humans and animals in China was approximately $3069 \mathrm{t} \mathrm{yr}^{-1}$ (Zhang et al., 2014). However, direct comparison among these data are difficult because they were estimated based on different sites and time scales.

Sex hormones are widely detected in concentrated animal feeding operations and wastewater treatment plants (Chang et al., 2011; Liu et al., 2012b; Liu et al., 2012c; Liu et al., 2015; Shen et al., 2019), and are subsequently released into surface waters and groundwaters, soils, and sediment via multiple pathways, including discharge of urban and rural wastewater, combined sewer overflows, agricultural runoff, and land application of manure waste, biosolids, and wastewater (Gall et al., 2011; Mansell et al., 2011; Liu et al., 2012c; Liu et al., 2015). Notably, sediment and soils are considered as the major sinks for sex hormones in the environment (Zhang et al., 2014). Zhang et al. (2014) predicted that approximately $80 \%$ of the human and animal excreted natural steroid hormones would end up in sediment and soils. The extent to which sex hormones are converted into transformation products (Qu et al., 2014; Yang et al., 2020a), get transported to surface waters and groundwaters (Kolodziej and Sedlak, 2007; Arnon et al., 2008; Mansell et al., 2011; Jones et al., 2014a; Duncan et al., 2015; Yang et al., 2020d), accumulated in crops and vegetables (He et al., 2015; Shargil et al., 2015), or are retarded by agricultural runoff management systems (e.g., vegetative filter strips and riparian buffers) (Jones et al., 2014b; Yang et al., 2019b; Yang et al., 2020b), will be highly dependent on their interactions with soils. In addition, whether sex hormones can be released from sediment back into waters will depend on their interactions with sediment (Sangster et al., 2016).

Given the importance of sex hormone-soil (or sediment) interactions on predicting their risks in the environment, we here systematically summarized the sorption-desorption data of sex hormones in soil- and sediment-water systems reported in the literature. The objectives of this review were to (i) summarize the sorption and desorption mechanisms of sex hormones in soil- and sediment-water systems; (ii) summarize the effects of environmental variables on sorption and desorption processes; and (iii) identify knowledge gaps and future research needs. Notably, the toxicity, occurrence, transformation, and transport of sex hormones in the environment were not specifically summarized in this review, because these data have been reviewed by other studies (Hanselman et al., 2003; Cwiertny et al., 2014; Fent, 2015; Kumar et al., 2015; Adeel et al., 2017; Zhao et al., 2019). Finally, we only collected available data for analysis because previous studies did not cover all the sex hormones.

\section{Structures and physiochemical properties of sex hormones}

Sex hormones are characterized by having a carbon skeleton with four fused rings conventionally denoted by the letters $A$, $B, C$, and $D$ (Fig. 1) (Hanselman et al., 2003; Adeel et al., 2017). The functional groups attached to the rings distinguish the different molecules. For example, estrogens contain one phenolic group, two cyclohexane rings, and one cyclopentane ring, with different functional groups at $\mathrm{C} 16$ and $\mathrm{C} 17$ position (Adeel et al., 2017). Estrone (E1) has a ketone group at $C 17$ position, while $17 \alpha$-estradiol (17 $\alpha$-E2) and $17 \beta$-estradiol (17 $\beta$ E2) have a hydroxy group attached to $\mathrm{C} 17$ with different orientations. Two hydroxy groups are attached to $\mathrm{C} 16$ and C17 position of estriol (E3). In addition, synthetic estrogen $17 \alpha$-ethinylestradiol (EE2) has an additional ethynyl on C17 position compared to $17 \beta-E 2$. Natural and synthetic androgens and progestins generally have similar skeleton as estrogens while contain different functional groups (Liu et al., 2009; Kumar et al., 2015).

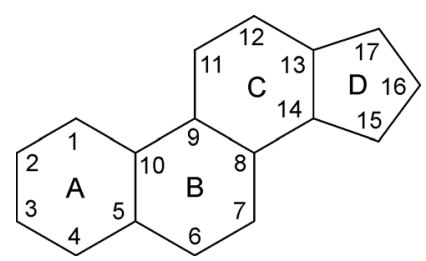

Fig. 1 General skeleton of sex hormones.

The physiochemical properties of the selected sex hormones are shown in Table 1 and Table S1. The octanol- 
Table 1 Structures and physicochemical properties of the selected sex hormones.

\section{Compound/MF $/ \mathrm{CAS}^{\mathrm{b}} / \mathrm{MW}^{\mathrm{c}}$}

Estrogens

Estrone (E1)

MF: $\mathrm{C}_{16} \mathrm{H}_{22} \mathrm{O}_{2}$

CAS: $53-16-7$

MW: 270.4

$17 \beta$-Estradiol (17 $\beta$-E2)

MF: $\mathrm{C}_{18} \mathrm{H}_{24} \mathrm{O}_{2}$

CAS: $50-28-2$

MW: 272.4

17a-Estradiol (17a-E2)

MF: $\mathrm{C}_{18} \mathrm{H}_{24} \mathrm{O}_{2}$

CAS: $57-91-0$

MW: 272.4

Estriol (E3)

MF: $\mathrm{C}_{18} \mathrm{H}_{24} \mathrm{O}_{3}$

CAS: $50-27-1$

MW: 288.4

17a-Ethinylestradiol (EE2)

MF: $\mathrm{C}_{20} \mathrm{H}_{24} \mathrm{O}_{2}$

CAS: $57-63-6$

MW: 296.4
Physiochemical properties

\begin{tabular}{l}
$\log K_{o w}^{d}: 3.43^{\mathrm{e}}, 3.55^{\mathrm{f}}, 2.95^{\mathrm{g}}$ \\
$S_{w}{ }^{\mathrm{h}}(\mathrm{mg} / \mathrm{L}): 146.8^{\mathrm{e}}, 3.94^{\mathrm{i}}$ \\
$p K_{a}^{\mathrm{j}}: 10.33^{\mathrm{i}}, 10.4^{\mathrm{k}}$ \\
$V P^{\mathrm{l}}(\mathrm{Pa}): 0.679^{\mathrm{e}}, 3 \times 10^{-5 \mathrm{~m}}$ \\
$\log K_{o w}: 3.94^{\mathrm{e}}, 3.70^{\mathrm{f}}, 3.86^{\mathrm{g}}$ \\
$S_{w}(\mathrm{mg} / \mathrm{L}): 81.97^{\mathrm{e}}, 21.3^{\mathrm{i}}$ \\
$p K_{a}: 10.33^{\mathrm{i}}, 10.23^{\mathrm{n}}$ \\
$V P(\mathrm{~Pa}): 2.65 \times 10^{-7 \mathrm{e}}, 3 \times 10^{-5 \mathrm{~m}}$ \\
$\log K_{o w}: 3.94^{\mathrm{e}}, 3.73^{\mathrm{f}}$ \\
$S_{w}(\mathrm{mg} / \mathrm{L}): 81.97^{\mathrm{e}}$ \\
$p K_{a}: \mathrm{NA}{ }^{\mathrm{o}}$ \\
$V P(\mathrm{~Pa}): 2.65 \times 10^{-7 \mathrm{e}}, 3 \times 10^{-5 m}$ \\
$\log K_{o w}: 2.81^{\mathrm{e}}, 2.45^{\mathrm{g}}, 2.6^{\mathrm{p}}$ \\
$S_{w}(\mathrm{mg} / \mathrm{L}): 440.8^{\mathrm{e}}, 119^{\mathrm{i}}$ \\
$p K_{a}: 10.33^{\mathrm{i}}, 10.05^{\mathrm{n}}$ \\
$V P(\mathrm{~Pa}): 1.25 \times 10^{-9 \mathrm{e}}, 3 \times 10^{-8 \mathrm{~m}}$ \\
$\log K_{o w}: 4.16^{\mathrm{e}}, 3.67^{\mathrm{g}}$ \\
$S_{w}(\mathrm{mg} / \mathrm{L}): 116.4^{\mathrm{e}}, 6.67^{\mathrm{i}}$ \\
$p K_{a}: 10.33^{\mathrm{i}}, 10.21^{\mathrm{n}}$ \\
$V P(\mathrm{~Pa}): 2.65 \times 10^{-7 \mathrm{~d}}, 6 \times 10^{-9 \mathrm{i}}$ \\
\hline
\end{tabular}

\section{ns}

Testosterone (TES)

$\log K_{\text {ow }}: 3.27^{\mathrm{e}}, 3.22^{\mathrm{p}}$

MF: $\mathrm{C}_{19} \mathrm{H}_{28} \mathrm{O}_{2}$

$S_{w}(\mathrm{mg} / \mathrm{L}): 67.76^{\mathrm{e}}, 33.3^{\mathrm{i}}$

CAS: $58-22-0$

$p K_{a}: 18.52^{i}$

MW: 288.42

$V P(\mathrm{~Pa}): 2.27 \times 10^{-6 e}$

17 $\beta$-Trenbolone (17 $\beta$-TBOH)

$\log K_{\text {ow: }}: 2.65^{\mathrm{e}}, 3.08^{\mathrm{q}}$

MF: $\mathrm{C}_{18} \mathrm{H}_{22} \mathrm{O}_{2}$

$S_{w}(\mathrm{mg} / \mathrm{L}): 324.1^{\mathrm{e}}, 58.6^{\mathrm{i}}$

CAS: 10161-33-8

$p K_{a}: 18.4^{i}$

MW: 270.37

$V P(\mathrm{~Pa}): 2.48 \times 10^{-6 e}$

17a-Trenbolone (17a-TBOH)

$\log K_{\text {ow: }}: 2.65^{\mathrm{e}}, 2.72^{\mathrm{q}}$

MF: $\mathrm{C}_{18} \mathrm{H}_{22} \mathrm{O}_{2}$

$S_{w}(\mathrm{mg} / \mathrm{L}): 324.1^{\mathrm{e}}$

CAS: 80657-17-6

$p K_{a}: N A$

MW: 270.37

$V P(\mathrm{~Pa}): 2.48 \times 10^{-6 e}$

Trendione (TBO)

$\log K_{\text {ow }}: 2.13^{\mathrm{e}}, 2.63^{\mathrm{q}}$

MF: $\mathrm{C}_{18} \mathrm{H}_{20} \mathrm{O}_{2}$

$S_{w}(\mathrm{mg} / \mathrm{L}): 277.4^{\mathrm{e}}$

CAS: 4642-95-9

$p K_{a}: N A$

MW: 268.37

$V P(\mathrm{~Pa}): 2.28 \times 10^{-4 \mathrm{e}}$ 
(Continued)

\begin{tabular}{|c|c|}
\hline Compound/MF $/ \mathrm{CAS}^{\mathrm{b}} / \mathrm{MW}^{\mathrm{c}}$ & Physiochemical properties \\
\hline 17a-Methyltestosterone (MT) & $\log K_{\text {ow: }}: 3.72^{\mathrm{e}}, 3.36^{\mathrm{r}}$ \\
\hline MF: $\mathrm{C}_{20} \mathrm{H}_{30} \mathrm{O}_{2}$ & $S_{w}(\mathrm{mg} / \mathrm{L}): 22.45^{\mathrm{e}}, 13.9^{\mathrm{i}}, 3.4^{\mathrm{r}}$ \\
\hline CAS: $58-18-4$ & $p K_{a}: 19.09^{i}$ \\
\hline MW: 302.45 & $V P(\mathrm{~Pa}): 1.84 \times 10^{-6 e}$ \\
\hline Androstenedione (AED) & $\log K_{o w}: 2.76^{\mathrm{e}}$ \\
\hline MF: $\mathrm{C}_{21} \mathrm{H}_{30} \mathrm{O}_{2}$ & $S_{w}(\mathrm{mg} / \mathrm{L}): 65.97^{\mathrm{e}}, 27^{\mathrm{i}}$ \\
\hline CAS: 63-05-8 & $p K_{a}: 19.03^{i}$ \\
\hline MW: 286.41 & $V P(\mathrm{~Pa}): 1.77 \times 10^{-6 \mathrm{e}}$ \\
\hline \multicolumn{2}{|l|}{ Progestins } \\
\hline Progesterone (P4) & $\log K_{\text {ow: }}: 3.67^{\mathrm{e}}$ \\
\hline MF: $\mathrm{C}_{21} \mathrm{H}_{30} \mathrm{O}_{2}$ & $S_{w}(\mathrm{mg} / \mathrm{L}): 5.00^{\mathrm{e}}, 5.46^{\mathrm{i}}$ \\
\hline CAS: $57-83-0$ & $p K_{a}: 18.47^{i}$ \\
\hline MW: 314.46 & $V P(\mathrm{~Pa}): 3.59 \times 10^{-4 \mathrm{e}}$ \\
\hline Altrenogest (ALT) & $\log K_{\text {ow: }}: 3.71^{\mathrm{e}}, 3.44^{\mathrm{s}}$ \\
\hline MF: $\mathrm{C}_{21} \mathrm{H}_{26} \mathrm{O}_{2}$ & $S_{w}(\mathrm{mg} / \mathrm{L}): 23.31^{\mathrm{e}}, 30.1^{\mathrm{i}}$ \\
\hline CAS: $850-52-2$ & $p K_{a}: 18.4^{i}$ \\
\hline MW: 310.44 & $V P(\mathrm{~Pa}): 1.04 \times 10^{-6 e}$ \\
\hline Chlormadinone acetate (CMA) & $\log K_{\text {ow: }}: 3.95^{\mathrm{e}}, 3.72^{\mathrm{s}}$ \\
\hline MF: $\mathrm{C}_{23} \mathrm{H}_{29} \mathrm{ClO}_{4}$ & $S_{w}(\mathrm{mg} / \mathrm{L}): 0.324^{t}$ \\
\hline CAS: 302-22-7 & $p K_{a}: N A$ \\
\hline MW: 404.93 & $V P(\mathrm{~Pa}): 4.3 \times 10^{-7 e}$ \\
\hline Megestrol acetate (MGA) & $\log K_{\text {ow: }}: 4.0^{\mathrm{e}}, 3.82^{\mathrm{s}}$ \\
\hline MF: $\mathrm{C}_{24} \mathrm{H}_{32} \mathrm{O}_{4}$ & $S_{w}(\mathrm{mg} / \mathrm{L}): 1.46^{\mathrm{e}}, 3.36^{\mathrm{i}}, 2.0^{\mathrm{t}}$ \\
\hline CAS: $595-33-5$ & $p K_{a}: 17.83^{i}$ \\
\hline MW: 384.51 & $V P(\mathrm{~Pa}): 5.83 \times 10^{-7 e}$ \\
\hline Drospirenone (DRO) & $\log K_{\text {ow }}: 4.02^{\mathrm{e}}, 3.12^{\mathrm{s}}$ \\
\hline MF: $\mathrm{C}_{24} \mathrm{H}_{30} \mathrm{O}_{3}$ & $S_{w}(\mathrm{mg} / \mathrm{L}): 0.46^{\mathrm{e}}, 2.25^{\mathrm{i}}$ \\
\hline CAS: $67392-87-4$ & $p K_{a}:-5^{i}$ \\
\hline MW: 366.49 & $V P(\mathrm{~Pa}): 2.98 \times 10^{-7 e}$ \\
\hline Medroxyprogesterone acetate (MPA) & $\log K_{o w}: 4.09^{d}, 3.85^{n}$ \\
\hline MF: $\mathrm{C}_{24} \mathrm{H}_{34} \mathrm{O}_{4}$ & $S_{w}(\mathrm{mg} / \mathrm{L}): 1.20^{\mathrm{e}}, 2.21^{\mathrm{i}}$ \\
\hline CAS: $71-58-9$ & $p K_{a}: 17.82^{i}$ \\
\hline MW: 386.52 & $V P(\mathrm{~Pa}): 8.94 \times 10^{-7 \mathrm{e}}$ \\
\hline Dienogest (DIE) & $\log K_{\text {ow: }}: 2.34^{\mathrm{e}}, 2.15^{\mathrm{s}}$ \\
\hline MF: $\mathrm{C}_{20} \mathrm{H}_{25} \mathrm{NO}_{2}$ & $S_{w}(\mathrm{mg} / \mathrm{L}): 57.1^{\mathrm{e}}, 76.1^{\mathrm{i}}$ \\
\hline CAS: $65928-58-7$ & $p K_{a}: 13.78^{i}$ \\
\hline MW: 311.42 & $V P(\mathrm{~Pa}): 1.67 \times 10^{-8 \mathrm{e}}$ \\
\hline
\end{tabular}


(Continued)

\begin{tabular}{|c|c|}
\hline Compound/MF $/ \mathrm{CAS}^{\mathrm{b}} / \mathrm{MW}^{\mathrm{c}}$ & Physiochemical properties \\
\hline Gestodene (GES) & $\log K_{\text {ow }}: 3.26^{\mathrm{e}}$ \\
\hline MF: $\mathrm{C}_{21} \mathrm{H}_{26} \mathrm{O}_{2}$ & $S_{w}(\mathrm{mg} / \mathrm{L}): 56.2^{\mathrm{e}}, 5.8^{\mathrm{i}}, 8.12^{\mathrm{t}}$ \\
\hline CAS: $60282-87-3$ & $p K_{a}: 17.08^{i}$ \\
\hline MW: 310.43 & $V P(\mathrm{~Pa}): 1.50 \times 10^{-7 \mathrm{e}}$ \\
\hline Levonorgestrel (LNG) & $\log K_{\text {ow }}: 3.48^{\mathrm{e}}$ \\
\hline MF: $\mathrm{C}_{21} \mathrm{H}_{28} \mathrm{O}_{2}$ & $S_{w}(\mathrm{mg} / \mathrm{L}): 35.8^{\mathrm{e}}, 5.8^{\mathrm{i}}, 2.05^{\mathrm{t}}$ \\
\hline CAS: 797-63-7 & $p K_{a}: 17.91^{i}$ \\
\hline MW: 312.45 & $V P(\mathrm{~Pa}): 1.34 \times 10^{-7 \mathrm{e}}$ \\
\hline Medroxyprogesterone (MPG) & $\log K_{\text {ow }}: 3.50^{\mathrm{e}}$ \\
\hline MF: $\mathrm{C}_{22} \mathrm{H}_{32} \mathrm{O}_{3}$ & $S_{w}(\mathrm{mg} / \mathrm{L}): 22.2^{\mathrm{e}}, 2.95^{\mathrm{t}}$ \\
\hline CAS: $520-85-4$ & $p K_{a}: N A$ \\
\hline MW: 344.49 & $V P(P a): 2.58 \times 10^{-8 e}$ \\
\hline Cyproterone acetate (CPA) & $\log K_{\text {ow }}: 4.18^{\mathrm{e}}, 3.1^{\mathrm{t}}$ \\
\hline MF: $\mathrm{C}_{24} \mathrm{H}_{29} \mathrm{ClO}_{4}$ & $S_{w}(\mathrm{mg} / \mathrm{L}): 0.65^{\mathrm{e}}, 1.5^{\mathrm{i}}, 51.7^{\mathrm{t}}$ \\
\hline CAS: $427-51-0$ & $p K_{a}: 17.83^{i}$ \\
\hline MW: 416.94 & $V P(\mathrm{~Pa}): 4.24 \times 10^{-7 e}$ \\
\hline Etonogestrel (ETO) & $\log K_{\text {ow }}: 3.89^{\mathrm{e}}, 3.16^{\mathrm{t}}$ \\
\hline MF: $\mathrm{C}_{22} \mathrm{H}_{28} \mathrm{O}_{2}$ & $S_{w}(\mathrm{mg} / \mathrm{L}): 57.1^{\mathrm{e}}, 7.37^{\mathrm{i}}$ \\
\hline CAS: $54048-10-1$ & $p K_{a}: 17.99^{i}$ \\
\hline MW: 324.45 & $V P(\mathrm{~Pa}): 1.68 \times 10^{-7 e}$ \\
\hline Norgestrel $^{\mathrm{u}}$ (NGT) & $\log K_{\text {ow }}: 3.48^{\mathrm{e}}$ \\
\hline MF: $\mathrm{C}_{21} \mathrm{H}_{28} \mathrm{O}_{2}$ & $S_{w}(\mathrm{mg} / \mathrm{L}): 35.8^{\mathrm{e}}, 5.83^{\mathrm{i}}, 1.7^{\mathrm{t}}$ \\
\hline CAS: $6533-00-2$ & $p K_{a}: 17.91^{i}$ \\
\hline MW: 312.45 & $V P(P a): 1.34 \times 10^{-7 e}$ \\
\hline Melengestrol acetate (MLA) & $\log K_{\text {ow }}: 4.41^{\mathrm{e}}, 3.93^{\mathrm{f}}$ \\
\hline MF: $\mathrm{C}_{25} \mathrm{H}_{32} \mathrm{O}_{4}$ & $S_{w}(\mathrm{mg} / \mathrm{L}): 0.55^{\mathrm{e}}, 1.47^{\mathrm{i}}$ \\
\hline CAS: 2919-66-6 & $p K_{a}: 17.54^{i}$ \\
\hline MW: 396.52 & $V P(P a): 6.08 \times 10^{-7 e}$ \\
\hline
\end{tabular}

${ }^{a} \mathrm{MF}$ represents molecular formula. ${ }^{\mathrm{b}} \mathrm{CAS}$ represents chemical abstracts service. ${ }^{\mathrm{c}} \mathrm{MW}$ represents molecular weight. ${ }^{\mathrm{d}}$ log $\mathrm{K}_{\text {ow }}$ represents octanolwater partition coefficient. ${ }^{e} \log K_{\text {ow }}$ values were estimated by EPI (Estimation Program Interface) suite program (KOWWIN v4.11). ${ }^{f}$ log $K_{\text {ow }}$ values were obtained from Card et al. (2012a). ${ }^{g} \log K_{\text {ow }}$ values were obtained from Machatha and Yalkowsky (2005). ${ }^{\mathrm{h}} S_{w}$ represents water solubility. ${ }^{\mathrm{i}} S_{w}$ values were obtained from Wishart et al. (2018). ${ }^{j} p K_{a}$ represents dissociation constant. ${ }^{k} p K_{a}$ values were obtained from Nghiem and Schafer (2002). 'VP represents vapor pressure (Pa). ${ }^{m} V P$ values were obtained from Adeel et al. (2017). ${ }^{\mathrm{n}} p K_{a}$ values were obtained from Perrin et al. (1977). ${ }^{\circ} \mathrm{NA}$ : not available. ${ }^{\mathrm{p}} \log K_{\text {ow }}$ values were obtained from Lee et al. (2003). ${ }^{\mathrm{q}} \log K_{\text {ow }}$ values were obtained from Khan et al. $(2009 \mathrm{~b}) .{ }^{r}$ log $K_{\text {ow }}$ and $S_{w}$ values were obtained from Ong et al. (2012). ${ }^{\mathrm{s}} \log K_{\text {ow }}$ values were obtained from Yang et al. (2020a). ${ }^{\mathrm{t}} \log K_{\text {ow }}$ and $S_{w}$ values were obtained

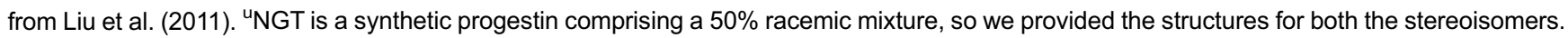


water partition coefficients $\left(\log K_{o w}\right)$ and water solubilities $\left(S_{w}\right)$ of the sex hormones are in the range of 2.13-4.41 and 0.324$440.8 \mathrm{mg} \mathrm{L}^{-1}$ (Wishart et al., 2018), respectively. Unlike persistent organic contaminants (e.g., polychlorinated biphenyls and polybrominated diphenyl ethers), sex hormones are generally moderately hydrophobic compounds with relatively high potential for transport in soil- and sediment-water systems. The vapor pressures (VPs) of the sex hormones are in the range of $1.25 \times 10^{-9}-0.679 \mathrm{~Pa}$, indicating that they are generally nonvolatile. In addition, the dissociation constants $\left(p K_{a}\right)$ for most of the sex hormones range from 10.05 to 19.09 , indicating that these compounds are weak acids and do not exist as ionic form under environmentally relevant $\mathrm{pH}$ values.

\section{Sorption and desorption isotherms}

Sorption data for the sex hormones in soil- and sedimentwater systems are commonly described by Freundlich and linear models, with limited studies using Langmuir models. Freundlich model assumes the multilayer sorption of target compounds on the heterogeneous surface of soil or sediment (Fuentes et al., 2014), which can be described as follows:

$$
\begin{gathered}
C_{s}=K_{f} \times C_{w}^{1 / n} \\
\log C_{s}=\log K_{f}+\frac{1}{n} \log C_{w}
\end{gathered}
$$

where $C_{s}$ is the solid phase concentration of a sex hormone, and $C_{w}$ is the aqueous phase concentration of a sex hormone at sorption equilibrium. $K_{f}$ and $1 / n$ are Freundlich sorption coefficient and Freundlich intensity parameter, respectively.

When $n$ equals unity, Freundlich model is converted to the linear model, which can be written as:

$$
C_{s}=K_{d} \times C_{w}
$$

where $K_{d}$ is the linear distribution coefficient. The organic carbon partition coefficient for sorption $\left(K_{o c}\right)$ can be normalized to soil or sediment organic carbon content $\left(f_{o c}\right)$ using the equation:

$$
K_{o c}=\frac{K_{d}}{f_{o c}}
$$

Langmuir model assumes that a sex hormone occupies specific homogeneous adsorption sites, which is considered as a monolayer sorption (Wu et al., 2003). Langmuir model can be described as follows:

$$
C_{s}=\frac{Q_{m} \times C_{w}}{1 / K+C_{w}}
$$

where $Q_{m}$ is the maximum sorption capacity, and $K$ is the sorption coefficient at equilibrium.

The desorption hysteresis index $(H I)$ (Huang et al., 1998) can be calculated as follows:

$$
H I=\frac{q_{e}^{d}-q_{e}^{s}}{q_{e}^{s}}
$$

where $q_{e}^{d}$ and $q_{e}^{s}$ are the solid phase concentrations of a sex hormone after desorption and sorption, respectively. Alternatively, the desorption hysteresis index $(H)$ (Yuan and Xing, 2001) can also be calculated as follows:

$$
H=\frac{1 / n_{d}}{1 / n_{s}}
$$

where $1 / n_{s}$ and $1 / n_{d}$ are the Freundlich intensity parameters obtained from sorption and desorption isotherms, respectively.

\section{General findings}

We collected 359 set of sorption data for the sex hormones based on existing literature (Supplementary information, SI, Tables S2-S4). These sorption studies were conducted in various soil- and sediment-water systems exhibiting a wide range of physiochemical properties such as organic carbon content (OC\%), particle size distribution, surface area (SA), and cation exchange capacity (CEC). In most cases, sorption data for the sex hormones were well-described by the linear model. Approximately 317, 142, and 34 data sets were derived from the linear, Freundlich, and Langmuir models, respectively. A total of 100 data sets were simultaneously derived from the linear and Freundlich models. In addition, 34 data sets were simultaneously derived from the linear, Freundlich, and Langmuir models (Qi et al., 2014; Ma et al., 2015; Hu et al., 2018). Langmuir models assumes that sorption takes place on a homogeneous adsorbent surface of identical sites that are equally available and energetically equivalent, with each site carrying equal numbers of molecules and no interaction between adsorbate molecules (Langmuir, 1918). Therefore, we suspect that Langmuir model was less used than other models because the surfaces of soil and sediment are generally heterogenous. Among the 142 data sets that were derived from the Freundlich model, the $n_{s}$ values for the sex hormones are mostly close to $1\left(n_{s}=0.92-\right.$ 1.08), indicating approximate linear sorption and relatively uniform sorption energies (Gineys et al., 2012). The linear isotherms or approximate linear isotherms are often considered as evidence of hydrophobic interaction driving sorption (Ying and Kookana, 2005; Khan et al., 2009a; Yang et al., $2019 b)$. However, the observed linear isotherms are sometimes due to relatively low sex hormone concentrations used for sorption experiments. In addition, some studies reported that other specific interactions also contributed to sorption despite observed linear isotherms (Khan et al., 2009a; Mashtare et al., 2011).

The reported $\log K_{o c}$ values of the selected sex hormones are summarized in Fig. 2. The $\log K_{o c}$ values of the estrogens, androgens, and progestins are in the range of 2.77-3.90, 2.55-4.18, and 2.61-4.39, respectively. In particular, the reported $\log K_{o c}$ values of chlormadinone acetate (CMA), EE2, testosterone (TES), drospirenone (DRO), medroxyprogesterone acetate (MPA), megestrol acetate (MGA), and 


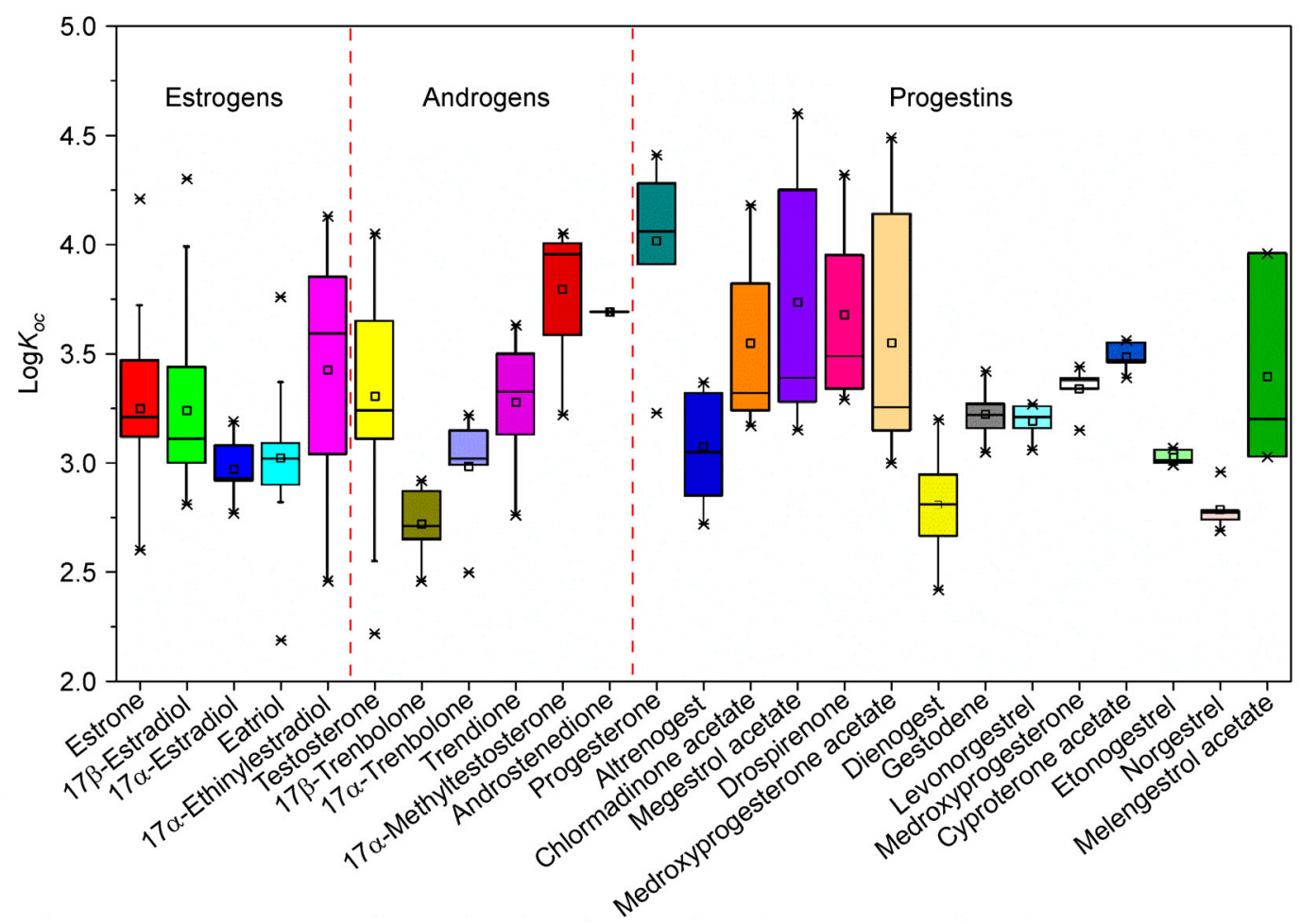

Fig. 2 The $\log K_{o c}$ values of the estrogens, androgens, and progestins reported in the literature (Tables S2-S4). The horizontal line and open symbol in a box represent the median and mean $\log K_{o c}$ value for a sex hormone. The bottom and top of a box are the first and third quartiles of the reported $\log K_{o c}$. Whisker is the minima and maxima of the reported $\log K_{o c}$.

melengestrol acetate (MLA) vary across relatively wide range (i.e., standard errors $=0.44-0.65$ ) (Fig. 2). These results could be due to (i) the presence of specific interactions in soil- and sediment-water systems (Sangster et al., 2015); (ii) significant different experimental and analytical approaches among sorption studies (Robinson et al., 2017); and (iii) diverse structures of soil or sediment organic matter (SOM) with different origins (Kulikova and Perminova, 2002).

\section{Factors responsible for the sorption of sex hormones in soil- and sediment-water systems}

\subsection{Structures and physiochemical properties of the sex hormones}

\subsection{1 log $K_{\text {ow }}$ values}

The $\log K_{\text {ow }}$ values of the sex hormones are critical factors affecting their distribution in soil- and sediment-water systems (Adeel et al., 2017; Zhao et al., 2019). In general, sex hormones with relatively higher $\log K_{\text {ow }}$ values are considered as more hydrophobic, and thus, are more likely to partition into soils via hydrophobic partitioning interaction (Yang et al., 2019c; Yang et al., 2020b). In this case, significant correlations between $\log K_{o c}\left(\right.$ or $\left.\log K_{d}\right)$ and $\log K_{\text {ow }}$ values of the sex hormones have sometimes been suggested as evidence of hydrophobic partitioning interaction driving sorption (i.e., hydrophobicity-dominated sorption) (Zhang et al., 2011; Yang et al., 2019b; Yang et al., 2020c). For example, Chen et al. (2012) found that the sorption magnitudes of 4 estrogens in soil-water systems were positively correlated with their $\log K_{\text {ow }}$ values $\left(R^{2}>0.92, p<0.01\right)$. Yang et al. $(2020 \mathrm{c})$ reported that the $\log K_{o c}$ values of 7 progestins were significantly correlated with their $\log K_{o w}$ values $\left(\log K_{o c}=\right.$ $\left.0.30 \log K_{\text {ow }}+1.91, R^{2}=0.70, p<0.01\right)$. These correlations, often named as single parameter linear free energy relationship (i.e., sp-LFERs, the relationships between $\log K_{o c}$ and a single solute property such as $\log K_{\text {ow }}$ and aqueous solubility), can be used to predict the the sorption magnitudes of other structurally similar sex hormones (Card et al., 2012b; Yang et al., 2020a). An alternative way to explore the effects of $\log K_{\text {ow }}$ on sorption is to develop the relationship between chromatographic retention times (RTs) of the sex hormones and their $\log K_{o c}$ values (Khan et al., 2009a; Yang et al., 2020b; Yang et al., 2020d). RTs can represent the relative hydrophobicity of the sex hormones, because the separation of the sex hormones in $\mathrm{C} 18$ chromatographic columns is generally based on pure partitioning mechanism (Karickhoff and Brown, 1979; Brooke et al., 1986; Woodburn et al., 1989).

In this review, correlation was developed between the $\log K_{o c}$ values of the sex hormones and their $\log K_{\text {ow }}$ values based on available data reported in the literature. We used $\log K_{\text {ow }}$ values estimated by EPI (Estimation Programs Interface) suite program (KOWWIN v4.11), instead of measured 
values, to prevent bias caused by experimental errors and different approaches for measuring $\log K_{\text {ow. }}$. The correlation between RTs and $\log K_{o c}$ values was not studied because RTs can vary greatly with the size of chromatographic columns, mobile phases, and elution gradients used for sex hormone analysis. These correlations would be expected to be effective only if the $\mathrm{C} 18$ column and analytical conditions are identical for each sex hormone. Here, the average log $K_{o c}$ values of the sex hormones are significantly correlated with their $\log K_{\text {ow }}$ values $\left(\log K_{o c}=0.22 \log K_{o w}+2.54,2.34<\log K_{o w}<4.41, R^{2}=\right.$ $0.13, p<0.05$ ) (Fig. 3), while the $R^{2}$ values are much lower than those obtained from correlations when fewer sex hormones were included for analysis (Yang et al., 2020a, 2020d). These results collectively indicate that hydrophobic partitioning interaction plays an important role in the uptake of the sex hormones in soil- and sediment-water systems, although other specific interactions can exist in the batch systems as well (Fig. 4).

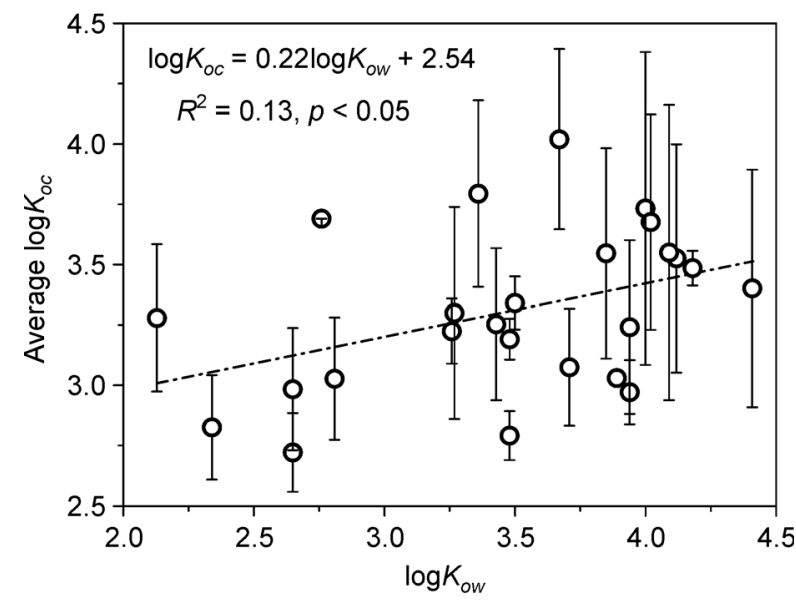

Fig. 3 Correlation between the reported $\log K_{o c}$ values of the sex hormones and their $\log K_{\text {ow }}$ values.

\subsubsection{Structural characteristics}

The cyclohexane rings, cyclopentane ring, methyl groups, methylene groups, and chlorine atoms are considered as the sources of hydrophobic force between the sex hormones and soils/sediment. The active functional groups of the sex hormones can provide additional contribution to their uptake in soil- and sediment-water systems. These structure-related specific interactions mainly include hydrogen bonding interaction (Stumpe and Marschner, 2007; Khan et al., 2009a; Mashtare et al., 2011; Yang et al., 2019b) and aromatic-type interaction (Yamamoto et al., 2003a; Stumpe and Marschner, 2007) (Fig. 4). Sex hormones contain ketone groups, hydroxy groups, or phenolic groups, which serve as hydrogen donors or acceptors that can facilitate the hydrogen bonding interaction with soil functionalities (Khan et al., 2009a; Mashtare et al., 2011; Yang et al., 2020d). The strength of hydrogen bonding interaction is dependent on the properties and orientations of the active functional groups. The mono- polar ketone group can only accept hydrogens rather than donate hydrogens, so it is less likely to form hydrogen bonding interaction with soils relative to bipolar hydroxy and phenolic groups. However, the presence of ketone group in the structure of a sex hormone may increase its overall sorption potential onto soils and sediment. Yang et al. (2019a) reported that trendione (TBO) exhibited higher sorption potential for soils relative to more hydrophobic $17 \alpha$-trenbolone (17 $\alpha$ $\mathrm{TBOH})$ and $17 \beta$-trenbolone $(17 \beta-\mathrm{TBOH})$. This phenomenon is because the $\mathrm{C} 17$ ketone group of TBO can only serve as hydrogen acceptor (i.e., trendione is less likely to form hydrogen bonding interaction with water) and thus, will decrease the overall hydrophilicity of TBO. The orientation of the functional groups also plays an important role in the strength of hydrogen bonding interaction. Two studies have explored the sorption of two pairs of stereoisomers, i.e., 17 $\alpha$ E2 and $17 \beta-E 2$, and $17 \alpha-\mathrm{TBOH}$ and $17 \beta-\mathrm{TBOH}$ onto soils, and found that the sorption magnitudes of $\beta$-isomers were nearly 2 times higher than those of respective $\alpha$-isomers (Khan et al., 2009a; Mashtare et al., 2011), because the-OH orientations of $\beta$-isomers favors the hydrogen bonding interaction with soils. Collectively, hydrogen bonding interaction is one of the most common interactions formed between the sex hormones and soils. Notably, whether hydrogen bonding interaction exist in a batch system could be explored by adding urea (a strong hydrogen bonding breaker) to batch systems or conducting Fourier transform infrared spectroscopy (FTIR) experiments before and after sorption. Yong et al. (2014) reported that in the presence of 0.1-2 $\mathrm{M}$ urea, the sorption magnitudes of TES onto clay and silt decreased by $5 \%-10 \%$. Similarly, some studies reported that in the presence of $0.5 \mathrm{M}$ urea, the $K_{d}$ values of natural and synthetic progestins decreased by 3\% - 19\% (Yang et al., 2020b; Yang et al., 2020d). In addition, Yang et al. (2020a) reported that the soil adsorption bands of Fourier transform infrared spectrum at $915 \mathrm{~cm}^{-1}$ and $3623 \mathrm{~cm}^{-1}$ (i.e., Al-OH vibrations of kaolinite) significantly changed after progestin sorption. It must be emphasized that FTIR experiments should be performed under relatively high concentrations due to low sensitivity of FTIR (Yang et al., 2020a).

Estrogens contain aromatic $A$ rings, which can interact with soils or sediment via $\pi-\pi$ bonding (Fig. 4). Lima et al. (2012) reported that the $K_{o c}$ values of EE2 were positively correlated with the aromatic units of organic matter (OM) due to $\pi-\pi$ bonding. Yamamoto et al. (2003a) reported that the $\log K_{o c}$ values of steroidal estrogens were not significantly correlated with their $\log K_{\text {ow }}$ values, but were especially sensitive to UV absorptivity at $272 \mathrm{~nm}$ and phenolic group concentration of the dissolved organic matter (DOM).

\subsection{Soil and sediment properties}

\subsubsection{Effects of SOM}

SOM strongly affect sex hormone distribution in soil- and sediment-water systems. SOM is a heterogeneous mixture, 


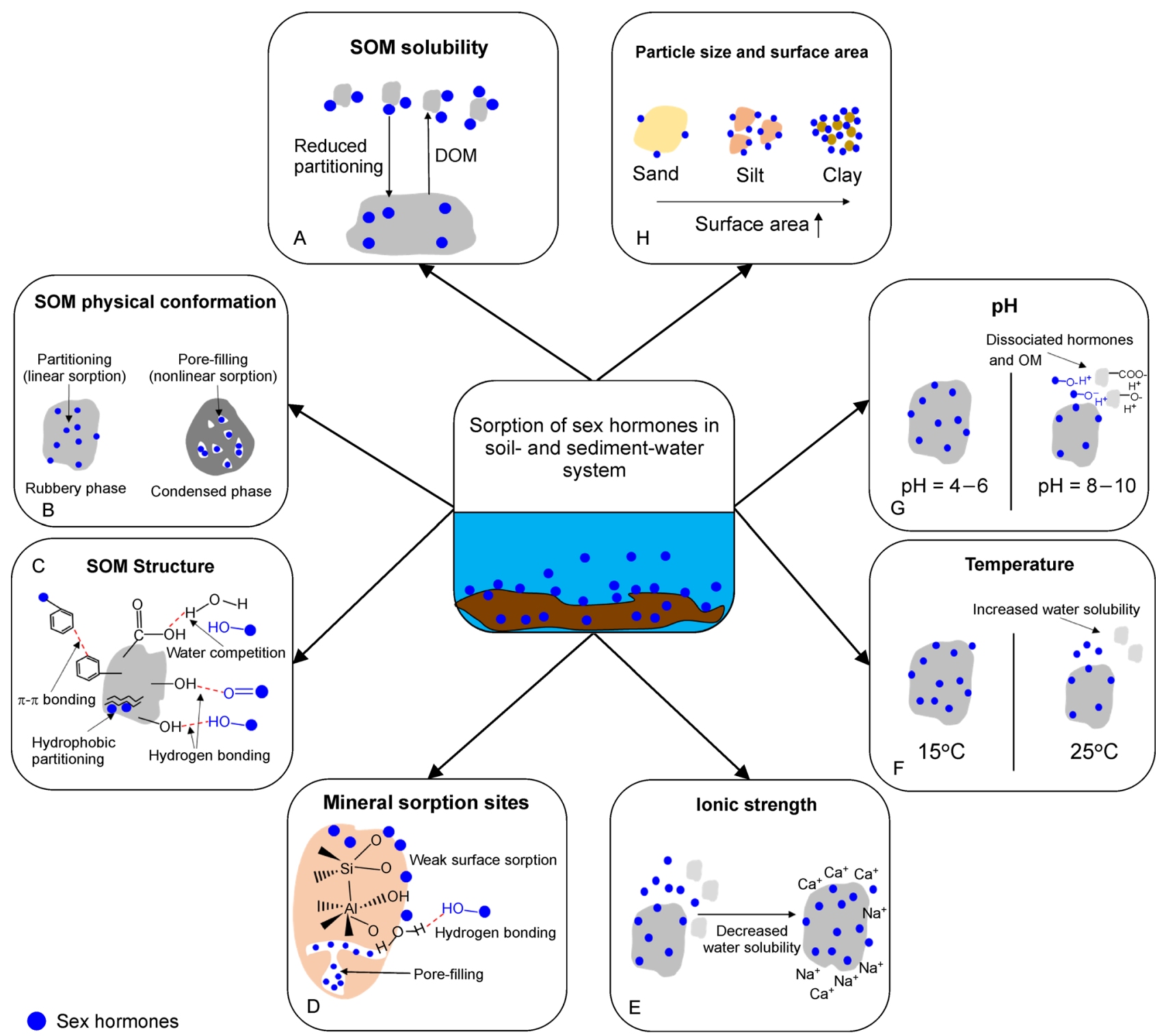

Fig. 4 The effects of (A) SOM solubility, (B) SOM physical conformation, (C) SOM and hormone structure, (D) mineral sorption sites, (E) ionic strength, $(\mathrm{F})$ temperature, $(\mathrm{G}) \mathrm{pH}$, and $(\mathrm{H})$ particle size and surface area on the uptake of sex hormones in soil- and sediment-water systems.

which includes newly deposited biopolymers (e.g., proteins, polysaccharides, and lipids), moderately aged humic substances (i.e., humic acid, fulvic acid, and humin), and well matured kerogen and black carbon (Song et al., 2002; Mechlińska et al., 2009). SOM often serves as the "organic phase", which can facilitate the hydrophobic partitioning of sex hormones onto soils and sediment (Lee et al., 2003; Boninand Simpson, 2007; Khan et al., 2009a; Caron et al., 2010; Mashtare et al., 2011; Yang et al., 2020d). For example, Khan et al. (2009a) found that the $K_{d}$ values of $17 \alpha-\mathrm{TBOH}, 17 \beta-$ $\mathrm{TBOH}$, and TBO were linearly correlated with the OC\% of five soils $\left(R^{2}=0.978-0.996\right)$. Similarly, Yang et al. (2020d) found that the $K_{d}$ values of etonogestrel (ETO), gestodene (GES), medroxyprogesterone (MPG), norgestrel (NGT), cyproterone acetate (CPA), levonorgestrel (LNG), and dienogest (DIE) were well-correlated with the OC\% of 5 agricultural soils $\left(R^{2}=\right.$ 0.84-0.98). Correlations were also developed between $K_{d}$ values of the sex hormones and OC\% of soils based on available data in the literature (Table 2). Notably, significant positive correlations are observed between the $K_{d}$ values of most sex hormones (i.e., 17 $\alpha$-E2, 17 $\beta$-E2, E1, E3, EE2, 17 $\alpha-$ $\mathrm{TBOH}, 17 \beta-\mathrm{TBOH}$, TBO, 17-methyltestosterone (MT), progesterone (P4), GES, MPG, CPA, and LNG) and corresponding OC\% $\left(R^{2}=0.16-0.99, p<0.05\right)$, indicating the importance of SOM-induced partitioning to overall sorption (Fig. 4).

Biopolymers (e.g., proteins, polysaccharides, lipids and lignin), humic acids, and fulvic acids are often classified as rubbery domain of SOM, while black carbon, kerogen, and humin are classified as condensed domain of SOM (Schamfuß et al., 2013). The condensed domain of SOM 
contains irregular pores and aromatic moieties, which can lead to isotherm nonlinearity due to pore filling and $\pi-\pi$ bonding. For example, Sun et al. (2010) reported the nonlinear sorption of EE2 onto condensed SOM (i.e., black carbon), with sorption magnitudes (i.e., log $K_{o c}$ ) much higher (5.4-12.9 times) than those of bulk soils. In contrast, the rubbery domain of SOM often contributes to the linear sorption isotherm (Fig. 4).

The structural characteristics of SOM could affect sorption as well. The aromatic domain of SOM can facilitate its interaction with estrogens via $\pi-\pi$ bonding (Sun et al., 2010; Lima et al., 2012). The polar groups of SOM could directly form hydrogen bonding interaction with the sex hormones. For example, Lima et al. (2012) reported that the carboxylic units of SOM were positively correlated with $K_{o c}$ values of EE2, a behavior likely due to specific polar interaction (hydrogen bonding interaction) between EE2 and SOM. In addition, the polar groups (e.g., hydroxyl, phenolic, and carboxyl groups) of SOM can also form hydrogen bonding interaction with water molecules, thereby reducing available sorption sites for sex hormones via competition effect (Guo et al., 2012) (Fig. 4).

Some domains of SOM can be dissolved into water, thus reducing the sorption of sex hormones in soil- and sedimentwater systems (Fig. 4). Yamamoto et al. (2003b) found that $17 \beta-E 2, E 3$, and EE2 can bind to DOM via $\pi-\pi$ bonding and hydrogen bonding interaction. Stumpe and Marschner (2010) observed that the presence of DOM in solution decreased the sorption of estrogens onto soils. Taken together, the quantity, physical conformation, structural characteristics, and solubility of SOM are essential to sex hormone uptake in soil- and sediment-water systems (Fig. 4).

\subsubsection{Effects of minerals}

The sorption magnitudes of organic contaminants in soil- and sediment-water systems are greatly affected by their interactions with minerals when the $\mathrm{OC} \%$ is very low (i.e., $<0.1 \%$ ). Mineral particles can be divided into sand (50 $\mu \mathrm{m}-2 \mathrm{~mm})$, silt $(2 \mu \mathrm{m}-50 \mu \mathrm{m})$, and clay $(<2 \mu \mathrm{m})$ based on particle size. Clay is considered as the most important sorbent for the sex hormones, which mainly includes kaolinite, smectite, and illite. These minerals are constructed by silicon-oxygen tetrahedral sheets and aluminum oxygen-hydroxyl octahedral sheet with the proportion of $1: 1$ or $2: 1$ (Deng et al., 2017). The hydrophobicity of the mineral surfaces is often critical to the sorption of hydrophobic organic contaminants onto clay minerals. However, clay mineral surfaces typically have strong affinities for water because the surfaces contain abundant metal cations, oxygen atoms, and hydroxyl groups (Cheng et al., 2012). Therefore, relatively polar organic contaminants can be readily adsorbed to soil and sediment minerals via cation exchange and bridge formed by hydrated cations (Zhao et al., 2015). However, cation exchange between clay mineral and hormones is not expected. The $p K_{a}$ values for the estrogens, progestins, and androgens are often>10 (Wishart et al., 2018), implying that they will not ionize at environmentally relevant $\mathrm{pH}$ values. Hydrogen bonding interaction is considered as an important sorption mechanism for the sex hormones, because their polar groups can react with oxygen atoms, hydroxyl groups or water molecule adsorbed on mineral surfaces (Wu et al., 2015) (Fig. 4).

In addition to hydrogen bonding interaction, sex hormones can interact with siloxane ( $\mathrm{Si}-\mathrm{O}-\mathrm{Si}$ ) bonds of kaolinite, illite, and montmorillonite surfaces via hydrophobic interaction (Van Emmerik et al., 2003) (Fig. 4). Moreover, sex hormones can further penetrate into the interlayer regions, micropores, or particle aggregates of water-expandable montmorillonite (i.e., diffusion-controlled sorption) via hydrophobic interaction and hydrogen bonding interaction (Cheng et al., 2012). For example, Shareef et al. (2006b) observed that $20 \%-60 \%$ of the initially spiked steroidal estrogens sorbed onto montmorillonite, while $<20 \%$ of those sorbed onto kaolinite. In addition, estrogens could be easily desorbed from illite and kaolinite, while estrogens can be barely desorbed from montmorillonite (Van Emmerik et al., 2003; Shareef et al., 2006b). Notably, the interactions between minerals and sex hormones will promote the understanding of colloid-facilitate transport of these compounds in soil-water systems (Shen et al., 2020).

Lai et al. (2000) reported that the sorption capacity of iron oxide for the estrogens accounted for $40 \%$ of that of a sediment with OC\% of $1.1 \%$. Apart from iron oxide, other common metal oxides (e.g., manganese oxides, ferrihydrite and silicon dioxide) often serve as catalysts, rather than effective sorbents, which are able to promote the abiotic transformation of the sex hormones in soil- and sedimentwater systems (Qu et al., 2014; Yang et al., 2020a). For example, 17 $\beta$-TBOH and MLA can experience oxidation, nucleophilic addition, or hydrolysis promoted by manganese oxides, ferrihydrite, and silicon dioxide (Qu et al., 2014).

5.2.3 Effects of cation exchange capacity, surface area and particle size distribution.

As shown in Table 2, the CEC values of soils and sediment positively affect the sorption of most sex hormones in soil- and sediment-water systems $\left(R^{2}=0.66-0.98, p<0.05\right)$. However, the $p K_{a}$ values of these hormones range from 10.05 to 19.09 , indicating that these compounds will not exist as cation under environmentally relevant $\mathrm{pH}$ values. Therefore, there are no direct evidence accounting for the high correlation between the $K_{d}$ values and CEC. Instead, two studies have reported that the CEC values were better-correlated with OM contents $\left(R^{2}=0.58-0.99\right)$ (Khan et al., 2009b; Yang et al., 2020a), because CEC is mainly originated from negatively charged groups of OM (Xiang et al., 2018). Therefore, the relatively high correlation between the sorption magnitudes of the sex hormones and CEC is attributable to the relatively high correlation between CEC and OM.

Correlations were also developed between the $K_{d}$ values of each hormone and particle size distribution (or SA) of soils and sediment (Table 2). Notably, the $K_{d}$ values of most sex hormones are not significantly correlated with the particle size distribution (i.e., sand $\%$, silt\%, clay $\%)\left(R^{2}=0.002-0.41\right.$, 
Table 2 Correlations between the $K_{d}$ values of the sex hormones and properties of soils and sediment reported in the literature. ${ }^{a}$

\begin{tabular}{|c|c|c|c|c|c|c|c|}
\hline Sex hormone & $\mathrm{N}^{\mathrm{b}}$ & OC\% & CEC $^{c}$ & $S A^{d}$ & Sand $\%{ }^{\mathrm{e}}$ & Silt $\%{ }^{\mathrm{e}}$ & Clay $\%{ }^{\mathrm{e}}$ \\
\hline Estrone & 46 & $0.16^{\star *}$ & $0.21^{\star *}$ & 0.005 & -0.006 & 0.002 & 0.002 \\
\hline 17a-Estradiol & 6 & $0.99^{* *}$ & $0.66^{*}$ & $N A^{f}$ & 0.05 & -0.006 & -0.11 \\
\hline $17 \beta$-Estradiol & 64 & $0.21^{* *}$ & $0.36^{\star *}$ & 0.003 & 0.002 & 0.07 & -0.002 \\
\hline Estriol & 27 & $0.34^{\star *}$ & $0.50^{\star *}$ & NA & -0.11 & 0.01 & 0.08 \\
\hline 17a-Ethinylestradiol & 20 & 0.16 & $0.49^{*}$ & -0.08 & 0.04 & 0.08 & 0.004 \\
\hline Testosterone & 51 & $0.09^{*}$ & $0.70^{\star \star}$ & $0.41^{* *}$ & -0.11 & -0.11 & $0.68^{* *}$ \\
\hline 17a-Trenbolone & 11 & $0.98^{* *}$ & $0.77^{\star}$ & NA & -0.007 & 0.34 & -0.23 \\
\hline $17 \beta$-Trenbolone & 6 & $0.98^{* *}$ & 0.76 & NA & -0.009 & 0.36 & -0.24 \\
\hline Trendione & 11 & $0.98^{\star *}$ & $0.84^{*}$ & NA & -0.03 & 0.41 & -0.2 \\
\hline 17a-Methyltestosterone & 5 & $0.97^{\star *}$ & NA & 0.15 & -0.56 & 0.45 & 0.61 \\
\hline Progesterone & 8 & $0.61^{*}$ & $0.88^{* \star}$ & $0.87^{\star \star}$ & NA & NA & NA \\
\hline Altrenogest & 6 & 0.63 & $0.92^{* *}$ & 0.58 & -0.41 & 0.36 & 0.28 \\
\hline Chlormadinone acetate & 5 & 0.004 & 0.46 & 0.15 & -0.7 & 0.58 & 0.59 \\
\hline Megestrol acetate & 5 & 0.003 & 0.38 & 0.08 & -0.61 & 0.5 & 0.53 \\
\hline Drospirenone & 5 & 0.01 & 0.47 & 0.16 & -0.61 & 0.6 & 0.57 \\
\hline Medroxyprogesterone acetate & 6 & 0.03 & 0.38 & 0.08 & -0.61 & 0.49 & 0.53 \\
\hline Dienogest & 10 & $0.69^{* *}$ & $0.94^{\star *}$ & $0.75^{\star \star}$ & $-0.72^{* *}$ & $0.73^{\star *}$ & 0.2 \\
\hline Gestodene & 5 & $0.87^{*}$ & $0.98^{* *}$ & 0.62 & $-0.77^{*}$ & $0.81^{*}$ & 0.03 \\
\hline Levonorgestrel & 5 & $0.91^{*}$ & $0.98^{* *}$ & 0.69 & $-0.82^{*}$ & $0.82^{*}$ & 0.07 \\
\hline Medroxyprogesterone & 5 & $0.85^{\star}$ & $0.97^{\star *}$ & 0.63 & -0.69 & $0.79^{*}$ & 0.001 \\
\hline Cyproterone acetate & 5 & $0.99^{* *}$ & $0.96^{\star *}$ & $0.88^{*}$ & -0.75 & 0.74 & 0.07 \\
\hline Etonogestrel & 5 & $0.98^{* *}$ & $0.98^{\star *}$ & $0.83^{*}$ & $-0.79^{\star}$ & $0.78^{*}$ & 0.09 \\
\hline Norgestrel & 5 & $0.85^{*}$ & 0.75 & 0.63 & -0.34 & 0.36 & 0.03 \\
\hline Melengestrol acetate & 3 & 0.79 & 0.97 & NA & -0.99 & 0.98 & 0.99 \\
\hline
\end{tabular}

a Single asterisk $\left(^{*}\right)$ and double asterisk $\left(^{* *}\right)$ represent $p<0.05$ and $p<0.01$, respectively. The statistical analysis was performed by SPSS 14.0 . Correlations were developed by using the data collected from the literature (Tables S2-S4). ${ }^{\mathrm{b}} \mathrm{N}$ represents the amount of data for each hormone. ${ }^{\mathrm{c}}$ CEC: Cation exchange capacity. ${ }^{\mathrm{d}} \mathrm{SA}$ : Surface area. ${ }^{\mathrm{e}}$ Sand $\%$, silt\%, and clay\% represent particle size distribution.

$p>0.05)$ and SA of soils and sediment $\left(R^{2}=-0.08-0.63\right.$, $p>0.05)$. These observations indicate that $S A$ and particle size play a relatively minor role in sex hormone uptake (Sangster et al., 2015). In addition, significant correlation between particle size distribution and sorption magnitudes are sometimes because of high correlation between OC\% and particle size distribution (Casey et al., 2003; Caron et al., 2010). Moreover, it was reported that surface area will increase when soil and sediment texture become more fine (Lee et al., 2003; Qi et al., 2014) (Fig. 4). Taken together, it is difficult to explore the effects of SA and particle size separately. Future experiments should be designed to specially address this issue.

\subsubsection{Effects of temperature, $\mathrm{pH}$, and ionic strength}

Sorption processes are generally spontaneous and exother- mal (Qi et al., 2014). The relatively high temperature can weaken the hydrophobicity of the sex hormones and scatter the OM in the aqueous phase (Johnson et al., 1999), and thus, are unfavorable for sorption (Fig. 4). For example, Zhang et al. (2013) found that the $K_{f}$ values of E1 in sediment-water systems decreased by $18.03 \%$ when temperature increased from $20^{\circ} \mathrm{C}$ to $30^{\circ} \mathrm{C}$.

$\mathrm{pH}$ can affect the extent of dissociation of sex hormones and SOM (Fig. 4). The phenolic group of estrogens will gradually dissociate under alkaline conditions $(\mathrm{pH}>8.7)$ (Zhang et al., 2013), forming an organic anion that can reduce their sorption magnitudes in soil- and sediment-water systems. Zhang et al. (2013) observed that the sorption magnitude of $\mathrm{E} 1$ on sediment remained basically unchanged when $\mathrm{pH}$ ranged from 5 to 8 , but decreased approximately by $29.4 \%$ when $\mathrm{pH}$ increased from 8 to 11 . Most progestins and 
androgens have no dissociable functional groups, thereby the sorption of these compounds can barely be affected by $\mathrm{pH}$ changes.

Humic acid and fulvic acid of SOM contain dissociable functional groups (e.g., carboxylic group). The $p K_{a}$ values for humic and fulvic acids were reported to be 4.26 and 2.18 (Neale et al., 2009), respectively, indicating that they can easily dissociate under neural or basic condition (Fig. 4). Neale et al. (2009) reported that the sorption magnitudes of steroid hormones on $\mathrm{OM}$ at acidic $\mathrm{pH}$ remained the highest while decreased by up to 14 times under alkaline condition, because $\mathrm{OM}$ was in the non-dissociated form under acidic $\mathrm{pH}$ conditions.

Many studies have shown that increases of solution ionic strength will evidently promote the sorption capacities of sex hormones due to salting out effect (Bowman et al., 2002; Sun et al., 2009; Ong et al., 2012) (Fig. 4). The salting out effects can be explained by several aspects. First, hydrophobic interaction is the main mechanism for sex hormone sorption in soil- and sediment-water systems. Relatively high ionic strength would push the sex hormones onto the soil or sediment surfaces and thereby reduce the water solubilities of sex hormones (Zhang et al., 2013). Second, relatively high ionic strength can also increase the hydrophobicity of SOM through a reduction in the charge of particle and the modification of SOM structure (Yang et al., 2005; Cao et al., 2011). For example, Sun et al. (2009) observed that the fluorescence intensities of dissolved humic acids strongly decreased in the presence of $\mathrm{Ca}^{2+}$ or $\mathrm{Na}^{+}$, which indicated relatively high salinity probably enhanced the hydrophobicity of SOM through a reduction in the dissociation of the SOM components (e.g., humic acid and fulvic acid). Ong et al. (2012) observed that the $K_{d}$ value of MT on sediment in the presence of $20 \mathrm{~g} \mathrm{~L}^{-1}$ of $\mathrm{NaCl}$ was 2.13 times higher than that without salinity, while the $K_{d}$ value of MT on sand (OC\% was close to 0 ) remain relatively stable when the salinity increased from 0 to $20 \mathrm{~g} \mathrm{~L}^{-1}$. These observations also indicated that ionic strength can change the sorption magnitudes of the sex hormones by changing the physical or chemical properties of SOM.

\subsubsection{Effects of competitive solutes}

In multi-solute systems, sex hormones can compete for specific binding sites of soils or sediment. The extent of competition often depends on (i) available sorption sites of minerals and SOM; (ii) sex hormone concentrations; and (iii) relative hydrophobicity among sex hormones. Bonin and Simpson (2007) observed that the sorption magnitudes of E1, $17 \beta-E 2$, EE2 mixtures on kaolinite and montmorillonite reduced by $>50 \%$ relative to those obtained from single-solute systems. However, the sorption magnitudes of these estrogens did not decrease significantly in peat soil systems because peat soil can provide sufficient sorption sites for these compounds (Bonin and Simpson, 2007). Generally, the sorption magnitude of the primary sorbate at high concentration would not change significantly when the concentration of competing sorbate is low. For example, Yu et al. (2004) found that the $K_{o c}$ value of $17 \beta-E 2$ in binary-solute systems (17ß-E2 and E1) was approximately the same as that obtained from single-solute systems when E1 concentration was relatively low. However, they also observed that the sorption of E1 was considerably reduced by the presence of $17 \beta-E 2$ under a wide range of concentrations, because $17 \beta-E 2$ is more hydrophobic than $E 1$. This result is also consistent with findings of Lai et al. (2000), who suggested that hormones with high hydrophobicity are more competitive for binding sites than those with low hydrophobicity.

In addition to competitive sorption, synergistic sorption was also reported in multi-solute systems. Yu et al. (2004) reported that the interactions among E1, 17 $\beta-E 2$ and E3 exhibited a synergistic effect on the sorption of EE2. Li et al. (2013) found that bisphenol $A$ at low concentrations competed with EE2, while bisphenol at high concentrations promoted the sorption of EE2 in batch systems. However, the specific mechanisms responsible for the synergistic sorption have not yet been systematically explored. We suspect that synergistic sorption is because sex hormones in the solid phases can increase the hydrophobicity and aromaticity of SOM, which can in turn facilitate the partitioning of other sex hormones onto soils and sediment.

\section{Desorption hysteresis}

A final consideration is the extent to which sex hormones exhibit thermodynamic reversibility, a necessary detail for predicting their transport potential and risks in agroecosystems (Qu et al., 2014; Yang et al., 2020d). Sorption reversibility of a sex hormone can be determined via both quantitative and qualitative ways. Specifically, the overlap between sorption and desorption isotherms of a sex hormone is considered as reversible sorption, while the lack of overlap indicates irreversible sorption (Durán-Álvarez et al., 2014; Qu et al., 2014). The irreversible sorption can also be evidenced by nearly identical solid phase concentrations of a sex hormone after sorption and desorption equilibration (Qu et al., 2014; Yang et al., 2020a). In a more quantitative way, the extent of sorption reversibility is expressed as $H I$ and $H$ (Eqs. (6) and (7). A value of $H I<0$ indicates that the sorption process is partially reversible, while $H I \geqslant 0$ indicates significant desorption hysteresis. For comparison, if $H$ is close to 1 , there is no (or very limited) desorption hysteresis (i.e., the desorption rate is similar to sorption rate). $H<1$ suggests the presence of hysteresis (i.e., the desorption rate is lower than sorption rate) (Doretto et al., 2014). However, there is no consensus on an indicative value for the presence or absence of hysteresis. For example, some studies reported that no hysteresis is present when $0.7<H<1$ (Barriuso et al., 1994).

In general, desorption hysteresis can be attributed to (i) irreversible binding of a sex hormone to SOM or clay minerals (Bhandari et al., 1996); and (ii) entrapment of sorbed molecules in mesoporous and microporous structures of 
condensed OM (e.g., black carbon and nonhydrolyzable carbon) or clay mineral (e.g., montmorillonite) (Shareef et al., 2006a; Sun et al., 2010; Cheng et al., 2012). Whether a sex hormone exhibits reversible sorption is dependent on several factors. First, sex hormones may exhibit relatively more significant desorption hysteresis at low concentrations (Durán-Álvarez et al., 2014) where chemical sorption dominates (Qi et al., 2014). Second, abundant sorption sites of SOM and active functional groups of the sex hormones are the prerequisite for the irreversible sorption (Qu et al., 2014; Yang et al., 2020a). For example, Yang et al. (2020a) reported that several synthetic progestins exhibited no desorption hysteresis $(H I=-0.75$ to -0.22$)$ on one agricultural soil while exhibited significant desorption hysteresis $(H I=0.01-0.1)$ on another agricultural soil, although these soils have nearly identical $\mathrm{OC} \%$. Finally, the $\mathrm{HI}$ values that were obtained from one desorption cycle are often lower than those obtained from 3 to 4 desorption cycles (Alonso et al., 2011), because one desorption cycle can mainly desorb the weakly-bonded progestins on the soil and sediment surfaces (Yang et al., 2020d).

\section{Conclusions and future perspectives}

This paper reviewed the sorption and desorption mechanisms of sex hormones in soil- and sediment-water systems, and summarized the effects of various environmental variables on sorption process. The significant correlations observed between the $K_{d}$ values of the sex hormones and OC\% (or $\log K_{\text {ow }}$ values) indicate that hydrophobic partitioning interaction plays an important role in sex hormone uptake in soil- and sediment-water systems. Other specific interactions include hydrogen bonding interaction and aromatic-type interaction. The sorption potential of sex hormones in soil- and sedimentwater systems can be affected by various factors, including $\mathrm{SOM}$, minerals, $\mathrm{pH}$, temperature, and ion strength.

Although the sorption of sex hormones in soil-water systems have been widely reported, these compounds are often released into agricultural soils via manure fertilization or biosolid application. These agricultural practices indicate that sex hormones will not be directly exposed to soil particles. Instead, the manure- or biosolid-associated sex hormones can be desorbed and then interact with soil particles. Such dynamic desorption-sorption scenario is expected to be highly environmentally relevant. In addition, batch sorption experiments are often conducted under equilibrium conditions, whereas nonequilibrium processes often dominate in the fieldscale systems. The rainfall intensity and timing, irrigation frequency, and tillage methods will greatly affect their distribution in manure-soil-water systems, and thus, will determine their transport potential and risks in agroecosystems. In this case, future studies should focus on the coupled leaching and sorption processes of sex hormones under various environmental and farming conditions.

Finally, sediment-associated sex hormones can be des- orbed and directly pose risks to sensitive fish species. For example, exposure to sediment-associate progesterone can lead to significant reductions in the expression of vitellogenin in fathead minnows (Sangster et al., 2016). Although the sorption characteristics of the sex hormones in sedimentwater systems have been extensively studied, the desorption outcomes of sex hormones have rarely been reported. Moreover, many studies have reported that hydrophobicity cannot predict the sorption reversibility of sex hormones. Collectively, future studies should focus on the desorption mechanisms of the sex hormones in sediment-water systems and the effects of various factors on desorption.

\section{Conflict of interest}

The authors declare no conflict of interest.

\section{Acknowledgments}

This work was financially supported by the National Natural Science Foundation of China (No. U1901601, No. 41877063, and No. 41701345), National Key Research and Development Program of China (No. 2019YFC1804400).

\section{References}

Adeel, M., Song, X., Wang, Y., Francis, D., Yang, Y., 2017. Environmental impact of estrogens on human, animal and plant life: A critical review. Environment International 99, 107-119.

Alonso, D.G., Koskinen, W.C., Oliveira, R.S. Jr, Constantin, J., Mislankar, S., 2011. Sorption-desorption of indaziflam in selected agricultural soils. Journal of Agricultural and Food Chemistry 59, 13096-13101.

Arnon, S., Dahan, O., Elhanany, S., Cohen, K., Pankratov, I., Gross, A., Ronen, Z., Baram, S., Shore, L.S.J.E.S., 2008. Technology, transport of testosterone and estrogen from dairy-farm waste lagoons to groundwater. Environmental Science and Technology 42, 5521-5526.

Barriuso, E., Laird, D.A., Koskinen, W.C., Dowdy, R.H., 1994. Atrazine desorption from smectites. Soil Science Society of America Journal 58, 1632-1638.

Besse, J.P., Garric, J., 2009. Progestagens for human use, exposure and hazard assessment for the aquatic environment. Environmental Pollution 157, 3485-3494.

Bhandari, A., Novak, J.T., Berry, D.F., 1996. Binding of 4-monochlorophenol to soil. Environmental Science \& Technology 30, 23052311.

Bonin, J.L., Simpson, M.J., 2007. Sorption of steroid estrogens to soil and soil constituents in single- and multi-sorbate systems. Environmental Toxicology and Chemistry 26, 2604-2610.

Bowman, J.C., Zhou, J.L., Readman, J.W., 2002. Sediment-water interactions of natural oestrogens under estuarine conditions. Marine Chemistry 77, 263-276.

Brooke, D.N., Dobbs, A.J., Williams, N., 1986. Octanol:water partition coefficients $(P)$ : measurement, estimation, and interpretation, 
particularly for chemicals with $P>10^{5}$. Ecotoxicology and Environmental Safety 11, 251-260.

Cao, X., Yang, G., Wei, S., Han, H., 2011. Sorption of heavy oil onto Jiaozhou Bay sediment. Marine Pollution Bulletin 62, 741-746.

Card, M.L., Chin, Y.P., Lee, L.S., Khan, B., 2012a. Prediction and experimental evaluation of soil sorption by natural hormones and hormone mimics. Journal of Agricultural and Food Chemistry 60, 1480-1487.

Card, M.L., Chin, Y.P., Lee, L.S., Khan, B., 2012b. Prediction and experimental evaluation of soil sorption by natural hormones and hormone mimics. Journal of Agricultural and Food Chemistry 60, 1480-1487.

Caron, E., Farenhorst, A., Zvomuya, F., Gaultier, J., Rank, N., Goddard, T., Sheedy, C., 2010. Sorption of four estrogens by surface soils from 41 cultivated fields in Alberta, Canada. Geoderma 155, 19-30.

Casey, F.X.M., Larsen, G.L., Hakk, H., Simůnek, J., 2003. Fate and transport of 17 beta-estradiol in soil-water systems. Environmental Science \& Technology 37, 2400-2409.

Chang, H., Wan, Y., Wu, S., Fan, Z., Hu, J., 2011. Occurrence of androgens and progestogens in wastewater treatment plants and receiving river waters: comparison to estrogens. Water Research 45, 732-740.

Chen, T.C., Chen, T.S., Yeh, K.J., Lin, Y.C., Chao, H.R., Yeh, Y.L., 2012. Sorption of estrogens estrone, 17 beta-estradiol, estriol, 17 alpha-ethinylestradiol, and diethylstilbestrol on sediment affected by different origins. Journal of Environmental Science and Health Part a-Toxic/Hazardous Substances \& Environmental Engineering 47, 1768-1775.

Cheng, H., Hu, E., Hu, Y., 2012. Impact of mineral micropores on transport and fate of organic contaminants: a review. Journal of Contaminant Hydrology 129-130, 80-90.

Cwiertny, D.M., Snyder, S.A., Schlenk, D., Kolodziej, E.P., 2014. Environmental designer drugs: when transformation may not eliminate risk. Environmental Science \& Technology 48, 1173711745.

Deng, L., Yuan, P., Liu, D., Annabi-Bergaya, F., Zhou, J., Chen, F., Liu, Z., 2017. Effects of microstructure of clay minerals, montmorillonite, kaolinite and halloysite, on their benzene adsorption behaviors. Applied Clay Science 143, 184-191.

Doretto, K.M., Peruchi, L.M., Rath, S., 2014. Sorption and desorption of sulfadimethoxine, sulfaquinoxaline and sulfamethazine antimicrobials in Brazilian soils. Science of the Total Environment 476477, 406- 414.

Duncan, L.A., Tyner, J.S., Buchanan, J.R., Hawkins, S.A., Lee, J., 2015. Fate and transport of $17 \beta$-estradiol beneath animal waste holding ponds. Journal of Environmental Quality 44, 982-988.

Durán-Álvarez, J.C., Prado, B., Ferroud, A., Juayerk, N., JiménezCisneros, B., 2014. Sorption, desorption and displacement of ibuprofen, estrone, and $17 \beta$ estradiol in wastewater irrigated and rainfed agricultural soils. Science of the Total Environment 473474, 189-198.

Fent, K., 2015. Progestins as endocrine disrupters in aquatic ecosystems: Concentrations, effects and risk assessment. Environment International 84, 115-130.

Fuentes, B., Mora, M.D., Bol, R., San Martin, F., Perez, E., Cartes, P.,
2014. Sorption of inositol hexaphosphate on desert soils. Geoderma 232, 573-580.

Gall, H.E., Sassman, S.A., Lee, L.S., Jafvert, C.T., 2011. Hormone discharges from a midwest tile-drained agroecosystem receiving animal wastes. Environmental Science \& Technology 45, 87558764.

Gambrell, R.D. Jr, Bagnell, C.A., Greenblatt, R.B., 1983. Role of estrogens and progesterone in the etiology and prevention of endometrial cancer: review. American Journal of Obstetrics and Gynecology 146, 696-707.

Gineys, N., Giroud, B., Gineys, M., Vulliet, E., 2012. Retention of selected steroids on a silt-loam soil. Environmental Letters 47, 2133-2140.

Guo, X., Wang, X., Zhou, X., Kong, X., Tao, S., Xing, B., 2012. Sorption of four hydrophobic organic compounds by three chemically distinct polymers: role of chemical and physical composition. Environmental Science \& Technology 46, 72527259.

Hanselman, T.A., Graetz, D.A., Wilkie, A.C., 2003. Manure-borne estrogens as potential environmental contaminants: a review. Environmental Science \& Technology 37, 5471-5478.

He, D., Ye, X., Xiao, Y., Zhao, N., Long, J., Zhang, P., Fan, Y., Ding, S., Jin, X., Tian, C., Xu, S., Ying, C., 2015. Dietary exposure to endocrine disrupting chemicals in metropolitan population from China: a risk assessment based on probabilistic approach. Chemosphere 139, 2-8.

Hu, Y., Yang, Q., Sun, J., Chen, Q., Fan, J., Mei, X., 2018. Adsorption and desorption behaviors of four endocrine disrupting chemicals in soils from the water-level fluctuation zone of the Three Gorges Reservoir, China. Sustainability 10, 2531.

Huang, W., Yu, H., Weber, W.J. Jr, 1998. Hysteresis in the sorption and desorption of hydrophobic organic contaminants by soils and sediments: 1. A comparative analysis of experimental protocols. Journal of Contaminant Hydrology 31, 129-148.

Johnson, M.D., Huang, W., Dang, Z., Weber, W.J. Jr, 1999. A distributed reactivity model for sorption by soils and sediments. 12 . Effects of subcritical water extraction and alterations of soil organic matter on sorption equilibria. Environmental Science \& Technology 33, 1657-1663.

Jones, G.D., Benchetler, P.V., Tate, K.W., Kolodziej, E.P., 2014a. Trenbolone acetate metabolite transport in rangelands and irrigated pasture: observations and conceptual approaches for agro-ecosystems. Environmental Science \& Technology 48, 12569-12576.

Jones, G.D., Benchetler, P.V., Tate, K.W., Kolodziej, E.P., 2014b. Surface and subsurface attenuation of trenbolone acetate metabolites and manure-derived constituents in irrigation runoff on agro-ecosystems. Environmental Science: Processes \& Impacts 16, 2507-2516.

Karickhoff, S.W., Brown, D.S., 1979. Determination of octanol/water distribution coefficients, water solubilities, and sediment/water partition coefficients for hydrophobic organic pollutants. EPA-600/ 4-79-032, Environmental Research Laboratory, Office of Research and Development, U.S. Environmental Protection Agency: Washington, DC.

Kavanaugh, M.L., Jerman, J., Finer, L.B., 2015. Changes in use of 
long-acting reversible contraceptive methods among U.S. women, 2009-2012. Obstetrics and Gynecology 126, 917-927.

Khan, B., Qiao, X., Lee, L.S., 2009a. Stereoselective sorption by agricultural soils and liquid-liquid partitioning of trenbolone (17alpha and 17beta) and trendione. Environmental Science \& Technology 43, 8827-8833.

Khan, B., Qiao, X., Lee, L.S., 2009b. Stereoselective sorption by agricultural soils and liquid-liquid partitioning of trenbolone (17a and $17 \beta$ ) and trendione. Environmental Science \& Technology 43, 8827-8833.

Kolodziej, E.P., Sedlak, D.L., 2007. Rangeland grazing as a source of steroid hormones to surface waters. Environmental Science \& Technology 41, 3514-3520.

Kulikova, N.A., Perminova, I.V., 2002. Binding of atrazine to humic substances from soil, peat and coal related to their structure. Environmental Science \& Technology 36, 3720-3724.

Kumar, V., Johnson, A.C., Trubiroha, A., Tumová, J., Ihara, M., Grabic, R., Kloas, W., Tanaka, H., Kroupová, H.K., 2015. The challenge presented by progestins in ecotoxicological research: a critical review. Critical Reviews in Environmental Science and Technology 49, 2625-2638.

Lai, K.M., Johnson, K.L., Scrimshaw, M.D., Lester, J.N., 2000. Binding of waterborne steroid estrogens to solid phases in river and estuarine systems. Environmental Science \& Technology 34, 3890-3894.

Lange, I.G., Daxenberger, A., Schiffer, B., Witters, H., Ibarreta, D., Meyer, H.H.D., 2002. Sex hormones originating from different livestock production systems: fate and potential disrupting activity in the environment. Analytica Chimica Acta 473, 27-37.

Langmuir, I., 1918. THE adsorption of gases on plane surfaces of glass, mica and platinum. Journal of the American Chemical Society 40, 1361-1403.

Lee, L.S., Strock, T.J., Sarmah, A.K., Rao, P.S.C., 2003. Sorption and dissipation of testosterone, estrogens, and their primary transformation products in soils and sediment. Environmental Science \& Technology 37, 4098-4105

Li, J., Jiang, L., Xiang, X., Xu, S., Wen, R., Liu, X., 2013. Competitive sorption between $17 \alpha$-ethinyl estradiol and bisphenol A/4-nnonylphenol by soils. Journal of Environmental Sciences (China) 25, 104-113.

Lima, D.L., Schneider, R.J., Esteves, V.I., 2012. Sorption behavior of EE2 on soils subjected to different long-term organic amendments. Science of the Total Environment 423, 120-124.

Liu, J., Wang, R., Huang, B., Lin, C., Zhou, J., Pan, X., 2012a. Biological effects and bioaccumulation of steroidal and phenolic endocrine disrupting chemicals in high-back crucian carp exposed to wastewater treatment plant effluents. Environmental Pollution 162, 325-331.

Liu, S., Ying, G.G., Zhang, R.Q., Zhou, L.J., Lai, H.J., Chen, Z.F., 2012b. Fate and occurrence of steroids in swine and dairy cattle farms with different farming scales and wastes disposal systems. Environmental Pollution 170, 190-201.

Liu, S., Ying, G.G., Zhou, L.J., Zhang, R.Q., Chen, Z.F., Lai, H.J., 2012c. Steroids in a typical swine farm and their release into the environment. Water Research 46, 3754-3768.

Liu, S.S., Ying, G.G., Liu, Y.S., Yang, Y.Y., He, L.Y., Chen, J., Liu, W.R.,
Zhao, J.L., 2015. Occurrence and removal of progestagens in two representative swine farms: Effectiveness of lagoon and digester treatment. Water Research 77, 146-154.

Liu, Z.H., Kanjo, Y., Mizutani, S., 2009. Urinary excretion rates of natural estrogens and androgens from humans, and their occurrence and fate in the environment: a review. Science of the Total Environment 407, 4975-4985.

Liu, Z.H., Ogejo, J.A., Pruden, A., Knowlton, K.F., 2011. Occurrence, fate and removal of synthetic oral contraceptives (SOCs) in the natural environment: a review. Science of the Total Environment 409, 5149-5161.

Lobo, R.A., 1992. The role of progestins in hormone replacement therapy. American Journal of Obstetrics and Gynecology 166, 1997-2004.

Ma, R., Zhang, T.C., Bartelt-Hunt, S.L., Qi, Y., Kranz, W.L., Snow, D. D., Mader, T.L., Shapiro, C.A., Shelton, D.P., van Donk, S.J., Tarkalson, D.D., Ensley, S., 2015. Influence of soil properties and test conditions on sorption and desorption of testosterone. Journal of Environmental Engineering 141, 04015006.

Machatha, S.G., Yalkowsky, S.H., 2005. Comparison of the octanol/ water partition coefficients calculated by $C \log \mathrm{P}^{\circledR}, \mathrm{ACD} \log \mathrm{P}$ and $\mathrm{KowWin}^{\circledR}$ to experimentally determined values. International Journal of Pharmaceutics 294, 185-192.

Mansell, D.S., Bryson, R.J., Harter, T., Webster, J.P., Kolodziej, E.P., Sedlak, D.L., 2011. Fate of endogenous steroid hormones in steer feedlots under simulated rainfall-induced runoff. Environmental Science \& Technology 45, 8811-8818.

Mashtare, M.L., Khan, B., Lee, L.S., 2011. Evaluating stereoselective sorption by soils of $17 \alpha$-estradiol and $17 \beta$-estradiol. Chemosphere 82, 847-852.

Mechlińska, A., Gdaniec-Pietryka, M., Wolska, L., Namieśnik, J., 2009. Evolution of models for sorption of PAHs and PCBs on geosorbents. Trends in Analytical Chemistry 28, 466-482.

Neale, P.A., Escher, B.I., Schäfer, A.I., 2009. pH dependence of steroid hormone-organic matter interactions at environmental concentrations. Science of the Total Environment 407, 1164-1173.

Nghiem, L.D., Schafer, A.I., 2002. Adsorption and transport of trace contaminant estrone in NF/RO membranes. Environmental Engineering Science 19, 441-451.

O'Loughlin, C.J., Karnam, U.S., Barkin, J.S., 2004. Effect of Gender on Pancreatic Disease. In: Legato, M.J., ed., Principles of GenderSpecific Medicine. Academic Press, San Diego, pp. 454-462.

Odom, E.B., Eisenberg, D.L., Fox, I.K., 2017. Difficult removal of subdermal contraceptive implants: a multidisciplinary approach involving a peripheral nerve expert. Contraception 96, 89-95.

Ong, S.K., Chotisukarn, P., Limpiyakorn, T., 2012. Sorption of 17 alpha-methyltestosterone onto soils and sediment. Water, Air, and Soil Pollution 223, 3869-3875.

Perrin, D.D., Dempsey, D.B., Serjeant, E.P., 1977. pKa Prediction for Organic Acids and Bases. Chapman and Hall.

Qi, Y., Zhang, T.C., Ren, Y., 2014. Testosterone sorption and desorption: effects of soil particle size. Journal of Hazardous Materials 279, 493-501.

Qu, S., Kolodziej, E.P., Cwiertny, D.M., 2014. Sorption and mineralpromoted transformation of synthetic hormone growth promoters in soil systems. Journal of Agricultural and Food Chemistry 62, 
$12277-12286$.

Robinson, J.A., Ma, Q., Staveley, J.P., Smolenski, W.J., 2017. Sorption and desorption of 17a-trenbolone and trendione on five soils. Environmental Toxicology and Chemistry 36, 613-620.

Runnalls, T.J., Beresford, N., Losty, E., Scott, A.P., Sumpter, J.P., 2013. Several synthetic progestins with different potencies adversely affect reproduction of fish. Environmental Science \& Technology 47, 2077-2084.

Runnalls, T.J., Margiotta-Casaluci, L., Kugathas, S., Sumpter, J.P., 2010. Pharmaceuticals in the aquatic environment: steroids and anti-steroids as high priorities for research. Human and Ecological Risk Assessment 16, 1318-1338.

Sangster, J.L., Ali, J.M., Snow, D.D., Kolok, A.S., Bartelt-Hunt, S.L., 2016. Bioavailability and fate of sediment-associated progesterone in aquatic systems. Environmental Science \& Technology 50, 4027-4036.

Sangster, J.L., Oke, H., Zhang, Y., Bartelt-Hunt, S.L., 2015. The effect of particle size on sorption of estrogens, androgens and progestagens in aquatic sediment. Journal of Hazardous Materials 299, 112-121.

Schamfuß, S., Neu, T.R., van der Meer, J.R., Tecon, R., Harms, H., Wick, L.Y., 2013. Impact of mycelia on the accessibility of fluorene to PAH-degrading bacteria. Environmental Science \& Technology 47, 6908-6915.

Shareef, A., Angove, M.J., Wells, J.D., Johnson, B.B., 2006 a. Sorption of bisphenol A, 17alpha-ethynylestradiol and estrone to mineral surfaces. Journal of Colloid and Interface Science 297, 62-69.

Shareef, A., Angove, M.J., Wells, J.D., Johnson, B.B., 2006b. Sorption of bisphenol A, 17a-ethynylestradiol and estrone to mineral surfaces. Journal of Colloid and Interface Science 297, 62-69.

Shargil, D., Gerstl, Z., Fine, P., Nitsan, I., Kurtzman, D., 2015. Impact of biosolids and wastewater effluent application to agricultural land on steroidal hormone content in lettuce plants. Science of the Total Environment 505, 357-366.

Shen, C., Jin, Y., Zhuang, J., Li, T., Xing, B., 2020. Role and importance of surface heterogeneities in transport of particles in saturated porous media. Critical Reviews in Environmental Science and Technology 50, 244-329.

Shen, X., Chang, H., Shao, B., Sun, F., Wu, F., 2019. Occurrence and mass balance of sixty-two progestins in a municipal sewage treatment plant. Water Research 165, 114991.

Song, J., Peng, P., Huang, W., 2002. Black carbon and kerogen in soils and sediments. 1. Quantification and characterization. Environmental Science \& Technology 36, 3960-3967.

Stumpe, B., Marschner, B., 2007. Long-term sewage sludge application and wastewater irrigation on the mineralization and sorption of $17 \beta$-estradiol and testosterone in soils. Science of the Total Environment 374, 282-291.

Stumpe, B., Marschner, B., 2010. Dissolved organic carbon from sewage sludge and manure can affect estrogen sorption and mineralization in soils. Environmental Pollution 158, 148-154.

Sun, K., Gao, B., Zhang, Z., Zhang, G., Liu, X., Zhao, Y., Xing, B., 2010. Sorption of endocrine disrupting chemicals by condensed organic matter in soils and sediments. Chemosphere 80, 709-715.
Sun, W., Ni, J., Li, T., Sun, L., 2009. Effect of $\mathrm{Ca}^{2+}$ and $\mathrm{Na}^{+}$on the sorption of three selected endocrine disruptors to sediments. Marine and Freshwater Research 60, 767-773.

Van Emmerik, T., Angove, M.J., Johnson, B.B., Wells, J.D., Fernandes, M.B., 2003. Sorption of $17 \beta$-estradiol onto selected soil minerals. Journal of Colloid and Interface Science 266, 33-39.

Wang, L., Ying, G.G., Zhao, J.L., Liu, S., Yang, B., Zhou, L.J., Tao, R., Su, H.C., 2011. Assessing estrogenic activity in surface water and sediment of the Liao River system in northeast China using combined chemical and biological tools. Environmental Pollution 159, 148-156.

Wishart, D.S., Feunang, Y.D., Guo, A.C., Lo, E.J., Marcu, A., Grant, J. R., Sajed, T., Johnson, D., Li, C., Sayeeda, Z., Assempour, N., lynkkaran, I., Liu, Y., Maciejewski, A., Gale, N., Wilson, A., Chin, L., Cummings, R., Le, D., Pon, A., Knox, C., Wilson, M., 2018. DrugBank 5.0: a major update to the DrugBank database for 2018. Nucleic Acids Research 46, D1074-D1082.

Woodburn, K., Lee, L., Rao, P., Delfino, J., 1989. Comparison of sorption energetics for hydrophobic organic chemicals by synthetic and natural sorbents from methanol/water solvent mixtures. Environmental Science \& Technology 23, 23.

Wu, P., Yang, G.P., Zhao, X.K., 2003. Sorption behavior of 2,4dichlorophenol on marine sediment. Journal of Colloid and Interface Science 265, 251-256.

Wu, Y., Si, Y., Zhou, D., Gao, J., 2015. Adsorption of diethyl phthalate ester to clay minerals. Chemosphere 119, 690-696.

Xiang, L., Xiao, T., Yu, P.F., Zhao, H.M., Mo, C.H., Li, Y.W., Li, H., Cai, Q.Y., Zhou, D.M., Wong, M.H., 2018. Mechanism and implication of the sorption of perfluorooctanoic acid by varying soil size fractions. Journal of Agricultural and Food Chemistry 66, 11569 11579.

Yamamoto, H., Liljestrand, H.M., Shimizu, Y., Morita, M., 2003a. Effects of physical-chemical characteristics on the sorption of selected endocrine disruptors by dissolved organic matter surrogates. Environmental Science \& Technology 37, 2646-2657.

Yamamoto, H., Liljestrand, H.M., Shimizu, Y., Morita, M., 2003b. Effects of physical-chemical characteristics on the sorption of selected endocrine disruptors by dissolved organic matter surrogates. Environmental Science \& Technology 37, 2646-2657.

Yang, G.P., Zhao, Y.H., Lu, X.L., Gao, X.C., 2005. Adsorption of methomyl on marine sediments. Colloids and Surface Physicochemical and Engineering Aspects 264, 179-186.

Yang, Q., Zhang, T.C., Ren, Y., 2014. Testosterone sorption and desorption: Effects of soil particle size. Journal of Hazardous Materials 279, 493-501.

Yang, X., Dai, X., Zhang, Y., Lin, H., Wang, J., He, Z., Li, Y., 2020a. Sorption, desorption, and transformation of synthetic progestins in soil and sediment systems. Geoderma 362, 114141.

Yang, X., Lin, H., Dai, X., Zhang, Z., Gong, B., Hu, Z., Jiang, X., Li, Y., $2020 \mathrm{~b}$. Sorption, transport, and transformation of natural and synthetic progestins in soil-water systems. Journal of Hazardous Materials 384, 121482.

Yang, X., Lin, H., Zhang, Y., He, Z., Dai, X., Zhang, Z., Li, Y., 2020c. Sorption and desorption of seven steroidal synthetic progestins in five agricultural soil-water systems. Ecotoxicology and Environmental Safety 196, 110586 
Yang, X., Lin, H., Zhang, Y., He, Z., Dai, X., Zhang, Z., Li, Y., 2020d. Sorption and desorption of seven steroidal synthetic progestins in five agricultural soil-water systems. Ecotoxicology and Environmental Safety 196, 110586.

Yang, X., Zhao, H., Cwiertny, D.M., Kolodziej, E.P., 2019a. Sorption and transport of trenbolone and altrenogest photoproducts in soilwater systems. Environmental Science. Processes \& Impacts 21, $1650-1663$.

Yang, X., Zhao, H., Cwiertny, D.M., Kolodziej, E.P., 2019b. Sorption and transport of trenbolone and altrenogest photoproducts in soilwater systems. Environmental Science. Processes \& Impacts 21, $1650-1663$.

Yang, X., Zhao, H., Cwiertny, D.M., Kolodziej, E.P., 2019c. Sorption and transport of trenbolone and altrenogest photoproducts in soilwater systems. Environmental Science. Processes \& Impacts 21, 1650-1663.

Ying, G.G., Kookana, R.S., 2005. Sorption and degradation of estrogen-like-endocrine disrupting chemicals in soil. Environmental Toxicology and Chemistry 24, 2640-2645.

Yu, Z., Xiao, B., Huang, W., Peng, P., 2004. Sorption of steroid estrogens to soils and sediments. Environmental Toxicology and Chemistry 23, 531-539.

Yuan, G., Xing, B., 2001. Effect of metal cations on sorption and desorption of organic compounds in humic acids. Soil Science 166, 107-115.

Zeilinger, J., Steger-Hartmann, T., Maser, E., Goller, S., Vonk, R., Länge, R., 2009. Effects of synthetic gestagens on fish reproduc- tion. Environmental Toxicology and Chemistry 28, 2663-2670.

Zhang, J., Yang, G.P., Li, Q., Cao, X., Liu, G., 2013. Study on the sorption behaviour of estrone on marine sediments. Marine Pollution Bulletin 76, 220-226.

Zhang, Q.Q., Zhao, J.L., Ying, G.G., Liu, Y.S., Pan, C.G., 2014. Emission estimation and multimedia fate modeling of seven steroids at the river basin scale in China. Environmental Science \& Technology 48, 7982-7992.

Zhang, Y., Wei, D., Huang, R., Yang, M., Zhang, S., Dou, X., Wang, D., Vimonses, V., 2011. Binding mechanisms and QSAR modeling of aromatic pollutant biosorption on Penicillium oxalicum biomass. Chemical Engineering Journal 166, 624-630.

Zhao, X., Grimes, K.L., Colosi, L.M., Lung, W.S., 2019. Attenuation, transport, and management of estrogens: A review. Chemosphere 230, 462-478.

Zhao, Y., Gu, X., Li, S., Han, R., Wang, G., 2015. Insights into tetracycline adsorption onto kaolinite and montmorillonite: experiments and modeling. Environmental Science and Pollution Research International 22, 17031-17040.

Zucchi, S., Castiglioni, S., Fent, K., 2012. Progestins and antiprogestins affect gene expression in early development in zebrafish (Danio rerio) at environmental concentrations. Environmental Science \& Technology 46, 5183-5192.

Zucchi, S., Castiglioni, S., Fent, K., 2013. Progesterone alters global transcription profiles at environmental concentrations in brain and ovary of female zebrafish (Danio rerio). Environmental Science \& Technology 47, 12548-12556. 